AperTO - Archivio Istituzionale Open Access dell'Università di Torino

\title{
Profiling of autochthonous microbiota and characterization of the dominant lactic acid bacteria occurring in fermented fish sausages
}

\section{This is a pre print version of the following article:}

Original Citation:

Availability:

This version is available http://hdl.handle.net/2318/1841465

since 2022-02-17T09:20:25Z

Published version:

DOI:10.1016/j.foodres.2022.110990

Terms of use:

Open Access

Anyone can freely access the full text of works made available as "Open Access". Works made available under a Creative Commons license can be used according to the terms and conditions of said license. Use of all other works requires consent of the right holder (author or publisher) if not exempted from copyright protection by the applicable law. 
Profiling of autochthonous microbiota and characterization of the dominant lactic acid bacteria occurring in fermented fish sausages produced in Southern Italy

Luca Belleggia $^{1}$, Ilario Ferrocino ${ }^{2}$, Maria Rita Corvaglia ${ }^{2}$, Cristiana Cesaro ${ }^{1}$, Vesna Milanović ${ }^{1}$, Federica Cardinali ${ }^{1}$, Cristiana Garofalo ${ }^{1}$, Luca Cocolin $^{2}$, Lucia Aquilanti $^{1}$, Andrea Osimani $^{1, *}$

${ }^{1}$ Dipartimento di Scienze Agrarie, Alimentari ed Ambientali, Università Politecnica delle Marche, via Brecce Bianche, Ancona, Italy

${ }^{2}$ Department of Agricultural, Forest, and Food Science, University of Turin, Largo Paolo Braccini 2, Grugliasco, Torino, Italy

* Corresponding author:

- Dipartimento di Scienze Agrarie, Alimentari ed Ambientali, Università Politecnica delle Marche, via Brecce Bianche, 60131, Ancona, Italy. E-mail address: a.osimani@univpm.it (AO) 


\begin{abstract}
In the present study, culture-dependent and metaxonomic sequencing were applied to study the natural microbiota of fermented fish sausages handcrafted in Southern Italy. Sausages were also subjected to histamine quantification and real-time PCR for the quantification of the Gram-positive and Gram-negative $h d c A$ and $h d c$ genes, respectively, that codifies for histidine decarboxylase enzyme. Autochthonous lactic acid bacteria isolated from fermented fish sausages were subjected to PCR to detect $h d c A$ gene, and of eps $A$, eps $B$, epsD/E, epsEFG, gtf, and lev genes, that codifies for the production of exopolysaccharides (EPS). Isolates were also screened for their ability to produce bacteriocins against Listeria innocua. In the analysed samples, high counts of presumptive lactic acid bacteria, coagulase-negative staphylococci, and eumycetes were detected. Moreover, Enterobacteriaceae,Pseudomonadaceae and enterococci were also detected. Regarding the microbiota composition, many bacteria and eumycetes commonly associated with fermented meat sausages were detected, thus suggesting their adaptation to a previously unexplored niche. Bacterial composition displayed the highest frequency of Latilactobacillus sakei, followed by Clostridium, Latilactobacillus curvatus, Peptostreptococcus, and Bacteroides. Eumycetic composition displayed the highest frequency of Kurtzmaniella zeylanoides, Rhodotorula mucilaginosa, Debaryomyces hansenii, Galactomyces, and Galactomyces geotrichum. Histamine content was highly variable among fish sausage samples, being comprised between $<4.2 \mathrm{mg} \mathrm{Kg}^{-1}$ and $299.6 \pm 13.5 \mathrm{mg} \mathrm{Kg}^{-1}$. The copy number of the $h d c A$ gene of Grampositive bacteria was below the detection limit in all the fermented fish sausage samples, whereas for the $h d c$ gene of Gram-negative bacteria, values between 5.20 \pm and 5.50 $\pm 0.26 \mathrm{Log}$ cells/gene copies $\mathrm{g}^{-1}$ were detected only in one batch. In the present study, 60 lactic acid bacteria isolates (22 isolates of $L$. sakei and 38 of $L$. curvauts) from fish sausage samples were obtained. None of the L. sakei or L. curvaus isolates exerted a bactericidal effect against L. innocua. Among the isolates tested for the production of saccharose-dependent EPS, 39 out of 60 showed the formation of mucoid colonies. Interestigly, 56 out 60 isolates were positive for the gene eps $D / E$, whereas 37 out of 60 isolates were positive for gene eps $A$, all these genes codifying for the production of heteropolysaccharides. Of note, the EPS production capability showed by many lactic acid bacteria isolates could represent a starting point for their future selection as adjunct cultures to improve texture and sensory traits of the fermented fish sausages under study. No autochthonous strains were positive for the presence of the $h d c A$ gene, thus suggesting their suitability for further testing as potential starter cultures. Further research is needed to understand microbial and physico-chemical changes occurring during fermentation.
\end{abstract}

Keywords: metataxonomic analysis; Latilactobacillus sakei; real-time PCR; histamine; hdcA gene 


\section{Introduction}

The use of fermentation to preserve fish is one of the most ancient and effective methods to extend the shelflife of this perishable food. Moreover, after fermentation, a range of flavorful taste compounds and aroma compounds are released in food matrix (Mouritsen et al., 2017), thus contributing to enhance the palatability of this product. The art of fish preservation dates back the Mesopotamians as early as the third millennium BC. Subsequently, the Ancient Romans were the major consumers of the so-called garum, a very famous fermented fish sauce imported from the East. Today, fermented fish preparations are very common in Asian countries as Japan, Thailand and Vietnam (Mouritsen et al., 2017; Zhao et al., 2019; Jang et al., 2017), Africa (Marti-Quijal et al., 2020), and in the northern Europe (Skåra et al., 2015). In Southern Italy, the so-called "Colatura di Alici di Cetara", which is a transparent liquid sauce with an amber color produced through ripening process of anchovies in a salt solution, represents a gastronomic excellence of undisputed value and attests the vocation of this Mediterranean area in the production of fermented fish products.

Usually, after fish harvesting, a rapid deterioration of flesh can occur due to the activity of autolytic enzymes and microorganisms such as Pseudomonas, Vibrio, Photobacterium, Serratia, Shewanella, Aeromonas, and those belonging to the family of Enterobacteriaceae, that naturally contaminate the fish gut and the environment (Zhou et al., 2021). To overcome this issue, fermentation process and eventually added ingredients allow spoilage microorganisms to be replaced by pro-technological microorganisms. Such a microbial succession leads to a safe preservation and a prolonged lifetime of the prepared foodstuff.

Among pro-technological microorganisms, lactic acid bacteria, naturally occurring in the raw material, or intentionally added as starter cultures, play a key role in driving fermentation, although many other microbial groups can be involved, depending on the process and the raw materials used. Lactic acid bacteria are a group of aero-tolerant Gram-positive bacilli or cocci, strictly fermentative, and organotrophic (Marti-Quijal et al., 2020). Homofermentative lactic acid bacteria produce lactate as the main final product of fermentation (MartiQuijal et al., 2020; Zhou et al., 2021), whereas heterofermentative species metabolize both hexoses and pentoses leading to different metabolites, including $\mathrm{CO}_{2}$, lactate and acetate or ethanol (Zotta et al., 2018). The microbial-derived organic acids lead to $\mathrm{pH}$ decrease with safety improvement and increase of the sensory characteristics of the product.

Besides the well-known acidifying activity, lactic acid bacteria exert many other biological activities that improve safety and rheological properties of the fermented product; among these activities, the production of bacteriocins and exopolysaccharides (EPS) is included.

By contrast, the metabolic activity of fermenting microorganisms can also exert adverse effects on the safety of foods by producing biogenic amines (e.g., histamine) that are precursors of carcinogenic N-nitroso compounds originating from the degradation of high-protein foods (Fong et al., 2021).

Hence, the success of the fermentation process is based on a fragile balance among the risks of crosscontamination, outcompeting wild fermentation, and occurrence of unwanted and potentially pathogenic fungal and bacterial species as well as toxic metabolites.

To the authors' knowledge, the use of fish flesh to produce fermented sausages is uncommon, especially in European countries where fermented sausages are mainly obtained using mammalian meat. Notwithstanding, in Southeast Asia, freshwater fish as Ophicephalus micropeltes, Notopterus spp., Probarbus jullieni, and Priacanthus tayenus are often used to produce fermented ground fish preparations (Khem et al., 2013). Moreover, Khem et al. (2013) developed a model fermented fish sausage from the marine species Pseudocaranx dentex, Arripis trutta and Macruronus novaezelandiae.

In the present study, different selective growth media and a metataxonomic approach were applied for the profiling of the microbiota naturally occurring in novel fermented fish sausages handcrafted in Southern Italy using marine fish species caught in the Mediterranean Sea. Sausages were also subjected to histamine quantification and a real-time PCR approach was used for the quantification of the Gram-positive and Gramnegative $h d c A$ and $h d c$ genes, respectively, in the food matrix. Moreover, in order to select lactic acid bacteria with potential pro-technological features, isolates obtained from the fermented fish sausages were subjected to PCR detection of the $h d c A$ gene and of some of the genes involved in the production of EPS. The lactic acid bacteria isolates were also screened for their ability to produce EPS on appropriate solid media and bacteriocins against Listeria innocua.

\section{Materials and methods}

\subsection{Sampling}


Nine ready-to-eat fish sausages were collected from three production batches of an artisan producer located in Matino, Lecce, Italy. The fish sausage samples were codified as follows: FS1-FS3 obtained from batch 1 (expiration date 03.2021), FS4-FS6 obtained from batch 2 (expiration date 08.2021) and FS7-FS9 obtained from batch 3 (expiration date 01.2021). All samples were analysed before their expiration date. Each sample of ready-to-eat fish sausage (150 g weight) was produced with yellowfin tuna (Thunnus albacares) $(50 \%)$, swordfish (Xiphias gladius) (30\%), amberjack (Seriola lalandi) (15\%), black pepper, garlic, cooked grape must, and mine salt. Fish sausages were stuffed into vegetable casings (not edible). Neither preservatives nor starter cultures were added. Prior to use, raw materials for the production of fish sausages have been subjected to a freezing treatment to prevent the risk of the parasite Anisakis sp. Defrosted fish were cut and trimmed to obtain fillets, that were subsequently sprinkled with salt, brown sugar and spices for a few days. Fish fillets were then cleaned of the excess marinade, minced and stuffed into vegetable casings. The fermentation was carried out in a seasoning cabinet at $20^{\circ} \mathrm{C}$ and a relative humidity of $70-80 \%$ for 60 days.

\subsection{Physico-chemical measurements}

For $\mathrm{pH}$ determination, a $\mathrm{pH}$ meter equipped with a HI2031 solid electrode (Hanna Instruments, Padova, Italy) was used at the core of the fish sausages. The water activity $\left(a_{\mathrm{w}}\right)$ was measured by means of Aqualab 4TE apparatus (Meter Group, Pullman, USA) in accordance with ISO 21807:2004 standard method. To determinate the total titratable acidity (TTA), 10 g-aliquots were sampled from each fish sausage and homogenized with $90 \mathrm{~mL}$ of demineralised water in a Stomacher 400 Circulator apparatus (VWR International PBI, Milan, Italy) at $260 \mathrm{rpm}$ for $3 \mathrm{~min}$. The TTA results were expressed as the total volume $(\mathrm{mL})$ of a $0.1 \mathrm{~N} \mathrm{NaOH}$ solution added to reach a fixed endpoint $\mathrm{pH}$ of 8.3. The D-/L-Lactic Acid (D-/L-Lactate) and Acetic Acid (ACS Manual Format) test kits (Megazyme, Bray, Ireland) were used to measure lactic acid and acetic acids contents, respectively, in accordance with the manufacturer's instructions. The analyses were performed in triplicate for each sample and the results were reported as mean \pm standard deviation.

Histamine Assay Kit (Megazyme) was used to measure the histamine content of fish sausages. In more detail, $2 \mathrm{~g}$ of each sample were crushed by the use of a sharp knife and subsequently added with $15 \mathrm{~mL}$ of sample extraction buffer (100 mM EDTA, pH 8.0) placed into a heat resistant tube. Samples were then boiled for 20 min and left to cool at room temperature. After the further addition of sample extraction buffer in order to reach the total volume of $25 \mathrm{~mL}$, sample was centrifuged at $10,000 \mathrm{rpm}$ for 5 minutes. The supernatant was used for histamine quantification, as described by the manufacturer's instructions. Three biological replicates were analysed and the results were reported as mean of $\mathrm{mg} \mathrm{Kg}^{-1} \pm$ standard deviation.

\subsection{Microbiological analyses}

To perform microbiological viable counts, 10 g-aliquots of each fish sausage were homogenized with $90 \mathrm{~mL}$ of peptone water (Oxoid, Milan, Italy) $(1 \mathrm{~g} / \mathrm{L})$ at $260 \mathrm{rpm}$ for $3 \mathrm{~min}$. The peptone water solution was used to carry out the serial ten-fold dilutions, in order to quantify the following microbial groups: (i) presumptive lactic acid bacteria, cultured on De Man, Rogosa and Sharpe (MRS) agar (VWR Prolabo Chemicals, Leuven, Belgium) (plus $250 \mathrm{mg} / \mathrm{L}$ of cycloheximide) with an incubation period of $48 \mathrm{~h}$ at $37^{\circ} \mathrm{C}$; (ii) coagulase negative staphylococci, cultured on Mannitol Salt Agar (MSA) (VWR Prolabo Chemicals) with an incubation period of 48-72 h at $37^{\circ} \mathrm{C}$; (iii) Enterobacteriaceae, cultured on Violet Red Bile Glucose Agar (VRBGA) (VWR Prolabo Chemicals) with an incubation period of $24 \mathrm{~h}$ at $37{ }^{\circ} \mathrm{C}$; (iv) Pseudomonadaceae, cultured on Pseudomonas Agar Base (PAB) (VWR Prolabo Chemicals), plus cetrimide-fucidin-cephalosporin (CFC) selective supplement (VWR International, Milan, Italy), with an incubation period of 24-48 $\mathrm{h}$ at $30{ }^{\circ} \mathrm{C}$; (v) enterococci, cultured on Enterococcus Selective Agar (Thermo Fisher Scientific, Buchs, Switzerland) with an incubation period of $48 \mathrm{~h}$ at $37^{\circ} \mathrm{C}$; (vi) eumycetes, cultured on Rose Bengal Chloramphenicol Agar (VWR Prolabo Chemicals) with an incubation period of $72-96 \mathrm{~h}$ at $25^{\circ} \mathrm{C}$. The analyses were performed in two biological and three technical replicates for each fish sausage and the results were expressed as the mean of Log of colony forming units (cfu) $\mathrm{g}^{-1} \pm$ standard deviation.

\subsection{DNA extraction and amplicon target sequencing}

From the homogenates (dilution $10^{-1}$ ) of each fish sausage sample, $1 \mathrm{~mL}$-aliquots were obtained. The aliquots, containing about $100 \mathrm{mg}$ of the respective sample, were centrifuged at $14,000 \mathrm{rpm}$ for $10 \mathrm{~min}$ and the 
supernatant was discarded. The pellets were processed for the total DNA extraction by using the E.Z.N.A. soil DNA kit (Omega Bio-tek, Norcross, GA, USA), in accordance with the manufacturer's instructions. To quantify the obtained DNA samples, the QUBIT dsDNA Assay kit (Life Technologies, Milan, Italy) was used. The fish sausage DNA samples were then diluted to $5 \mathrm{ng} / \mu \mathrm{L}$ to carry out the amplicon target sequencing. In more detail, the bacterial biota was evaluated by the amplification of the V3-V4 region of the 16S rRNA gene by using primers and protocols described by Klindworth et al. (2013). Moreover, the D1-D2 domain of the 26S was amplified for the mycobiota evaluation, as reported by Mota-Gutierrez (2018). PCR amplicons were purified, tagged and pooled in equimolar concentration in accordance with the metagenomic standard procedure of Illumina. Pair-end sequencing $(2 X 250 \mathrm{bp})$ was performed with a MiSeq Illumina workstation (Illumina) with V2 chemistry following the manufacturer's instructions.

\subsection{Bioinformatic analysis}

Raw reads were imported in QIIME2 software (Bolyen et al., 2019) and primers and adapters were first trimmed by using Cutadapter and then quality filtered by using the DADA2 algorithm (Callahan et al., 2016). Low-quality bases and chimeric sequences were filtered out through the DADA2 denoise-paired plug of QIIME2 to obtain the Amplicon Sequence Variants (ASVs). The Greengenes 16S rRNA gene database was used for the taxonomic assignment of the bacterial biota, whereas the manually build database was used for the mycobiota (Mota-Gutierrez et al., 2018). The resulting taxonomic assignment of each ASVs was doublechecked by Basic Local Alignment Search Tool (BLAST) performed manually. The sequencing data were deposited in the NCBI Sequence Read Archive (SRA) and are available under the Bioprojects Accession Number PRJNA769593

\subsection{Detection of histidine decarboxylases-codifying genes in food matrix}

DNAs obtained from the homogenates of fish sausage samples were subjected to qPCR in order to detect and quantify the $h d c A$ gene of Gram-positive bacteria. To this end, a Mastercycler ${ }^{\circledR}$ ep realplex machine (Eppendorf, Hamburg, Germany) was employed by following the cycling program already described by Belleggia et al., (2021). The primer set Hdc1 (5'-TTGACCGTATCTCAGTGAGTCCAT-3') plus Hdc2 (5'ACGGTCATACGAAACAATACCATC-3') was used to amplify the $h d c A$ gene fragment (174 bp) (Fernández et al., 2006). The reaction mixes contained $4 \mu \mathrm{L}$ of DNA sample, $5 \mu \mathrm{L}$ of Type-it $2 X$ HRM PCR Master Mix (QIAGEN), $900 \mathrm{nM}$ of both primers and nuclease-free molecular biology grade water to reach the final volume of $10 \mu \mathrm{L}$. The positive strain Lactobacillus parabuchneri DSM 5987 was utilized to construct the standard curve. In detail, the strain was subcultured on MRS medium and suspended on sterile saline solution $(0.85 \%$ $\mathrm{NaCl}, \mathrm{w} / \mathrm{v}$ ) to perform 10 -fold serially dilutions. The concentration of the undiluted suspension was calculated through the use of standard microbiological counting methods, including the Thomas cell counting chamber and plate viable counts on MRS agar. One $\mathrm{mL}$ of each dilution series point was subjected to DNA extraction, as described in paragraph 2.4. To create the standard curve, the $\mathrm{Ct}$ values of the qPCR performed on the extracted DNAs were plotted against the $h d c A$ gene copies of each reaction. The efficiency (E) and the correlation coefficient $\left(\mathrm{R}^{2}\right)$ of the $\mathrm{qPCR}$ were automatically computed from the slope of the standard curve by the Mastercycler ep realplex v2.2 software (Eppendorf). For each qPCR reaction of the samples, the absolute number of gene copies was obtained on the base of the standard curve, ranging from $\sim 10$ to $10^{6}$. Analyses were performed in technical triplicate, together with a blank. The results were expressed as the mean of Log gene copies or cells $\mathrm{g}^{-1} \pm$ standard deviation, as it is reported that histamine-producing Gram-positive bacteria contain a unique copy of the $h d c A$ gene (Satomi, 2016).

Likewise, the same DNA samples were subjected to qPCR for the detection of $h d c$ gene of Gram-negative bacteria. To this end, the analysis protocol optimized by Bjornsdottir-Butler et al. (2011) was applied with some modifications. In detail, the primer set hdc forward (5'-TCHATYARYAACTGYGGTGACTG-3') plus hdc reverse (5'-CCRTTRGTNACRTAVCCCCA-3') was used to amplify the $h d c$ gene fragment (139 bp) (Bjornsdottir-Butler et al., 2011). The reaction mixes contained $4 \mu \mathrm{L}$ of DNA sample, $5 \mu \mathrm{L}$ of Type-it $2 \mathrm{X}$ HRM PCR Master Mix (QIAGEN), $500 \mathrm{nM}$ of both primers and nuclease-free molecular biology grade water to reach the final volume of $10 \mu \mathrm{L}$. The positive strain Morganella morganii DSM 30117 was subcultured on BHI agar (VWR Prolabo Chemicals) and utilized to construct the standard curve, as already described in this paragraph. For each qPCR reaction of the samples, the absolute number of gene copies was obtained on the base of the standard curve, ranging from $\sim 10$ to $10^{6}$. Analyses were performed in technical triplicate, together 
with a blank. The results were expressed as the mean of Log gene copies or cells $\mathrm{g}^{-1} \pm$ standard deviation (Bjornsdottir-Butler et al., 2011).

\subsection{Statistical analysis}

To assess statistical differences within fish sausage samples, the Tukey-Kramer's Honest Significant Difference (HSD) test (level of significance 0.05 ) was used by one-way analysis of variance (ANOVA). Tests were performed through JMP v11.0.0 software (SAS Institute Inc., Cary, NC).

Alpha and beta diversity as well as permutational multivariate analysis of variance (ANOSIM) of the metataxonomic data were performed thought the diversity function of QIIME2. Microbiota as weel asmycobiota compositions were compared between the three batches by Wilcoxon rank sum test ( $\mathrm{P}$ value adjustment method: FDR).

\subsection{Characterization of the dominant lactic acid bacteria}

\subsubsection{Lactic acid bacteria isolation}

As previously described, lactic acid bacteria from fish sausage samples were cultured in MRS agar added with cycloheximide $(250 \mathrm{mg} / \mathrm{L})$ and the resulting colonies were randomly selected and subsequently sub-cultured to purity in the same conditions. The obtained isolates were then stored at $-80{ }^{\circ} \mathrm{C}$.

Prior to further analysis, lactic acid bacteria have been thawed and sub-cultured twice on MRS agar at $37^{\circ} \mathrm{C}$ for $48 \mathrm{~h}$. DNA of lactic acid bacteria isolates was extracted according to Osimani et al. (2015) and its purity and quantity were verified with a NanoDrop ND 1000 (Thermo Fisher Scientific, Wilmington, DE, USA). DNAs were standardized to a final concentration of $100 \mathrm{ng} / \mu \mathrm{L}$ and subjected to PCR in a My Cycler Thermal Cycler (BioRad Laboratories, Hercules, CA, USA) using the universal prokaryotic primers $27 \mathrm{f}$ and $1495 \mathrm{r}$, as described by Osimani et al. (2015). The amplification was verified by electrophoresis on $1.5 \%(\mathrm{w} / \mathrm{v})$ agarose gel in $0.5 \mathrm{X}$ Tris/Borate/EDTA (TBE) buffer containing $0.5 \mu \mathrm{g} / \mathrm{mL}$ GelRed ${ }^{\circledR}$ Nucleic Acid Gel Stain, 10,000X in water (Biotium, San Francisco Bay Area, USA). The electrophoretic run included the HyperLadder ${ }^{\mathrm{TM}} 1 \mathrm{~kb}$ (Meridian Bioscience, Cincinnati, Ohio, USA) as molecular weight standard and was carried out at $75 \mathrm{~V}$ for $3.5 \mathrm{~h}$ and visualized under UV light. The amplicons were then shipped to Genewiz (Takaley, UK) for their purification and sequencing.

The raw sequences of lactic acid bacteria isolates, represented in FASTA format, were analysed with UCHIME2 software tool to uncover chimeras (Edgar et al., 2016) and were trimmed to remove NNNs and misleading data from the terminations. Afterwards, a BLAST search was exploited to compare the obtained sequences with 16S rRNA sequences of type strains from GenBank DNA database (http://www.ncbi.nlm.nih.gov/). The sequences of the 60 lactic acid bacteria strains were finally submitted to GenBank DNA database to acquire the respective accession numbers.

\subsubsection{Molecular typing by REP-PCR of the lactic acid bacteria isolates}

Lactic acid bacteria fingerprints were obtained by using Repetitive Extragenic Palindromic PCR (REP-PCR) with the (GTG)5 primer (5'-GTGGTGGTGGTGGTG- 3'). PCR mixture (final volume of $25 \mu \mathrm{L}$ ) contained 1 $\mu \mathrm{L}$ of template DNA (100 ng), $0.5 \mu \mathrm{L}$ of (GTG) 5 primer $1 \mu \mathrm{M}, 0.5 \mu \mathrm{L}$ of dNTPs $(0.25 \mathrm{mM}$ each), $1.5 \mu \mathrm{L}$ $\mathrm{MgCl}_{2} 25 \mathrm{mM}, 2.5 \mu \mathrm{L}$ of 10X PCR buffer and $0.2 \mu \mathrm{L}$ of a $5 \mathrm{U}$ of DNA Polymerase (QIAGEN, Hilden, Germany). PCR conditions consisted of an initial cycle of $5 \mathrm{~min}$ at $95^{\circ} \mathrm{C}$ followed by 30 amplification cycles $\left(30 \mathrm{~s}\right.$ at $90^{\circ} \mathrm{C}, 1 \mathrm{~min}$ at $40^{\circ} \mathrm{C}, 8 \mathrm{~min}$ at $65^{\circ} \mathrm{C}$ ) plus one final chain elongation cycle for $16 \mathrm{~min}$ at $68^{\circ} \mathrm{C}$. PCR products were resolved by electrophoresis on $2 \%(\mathrm{w} / \mathrm{v})$ agarose gel in $0.5 \mathrm{X}$ TBE buffer at $120 \mathrm{~V}$ for $2 \mathrm{~h}$. The REP-PCR profiles were imported in the BioNumerics v6.1 software (Applied Maths, Sint-Martens-Latem, Belgium). The dendrograms were calculated on the basis of the Dice coefficient of similarity, with the unweighted pair group method by using average linkages (UPGMA) clustering algorithm (Vauterin L. \& Vauterin P., 1992). Principal Coordinates Analysis (PCoA) (dudi.pco function in made4 package of R) was carried out on the fingerprint matrix generated through BioNumerics calculated on Euclidean distance (vegdist function in package vegan $\mathrm{R}$ ).

\subsubsection{Detection of hdcA gene in lactic acid bacteria isolates}


The DNAs obtained from the 60 lactic acid bacteria strains isolated from fish sausage samples were tested for the presence of the $h d c A$ gene. In this case, a PCR was conducted in My Cycler Thermal Cycler (BioRad Laboratories) with the following conditions: an initial step of $3 \mathrm{~min}$ at $95^{\circ} \mathrm{C}, 40 \mathrm{amplification}$ cycles $(20 \mathrm{~s}$ at $95{ }^{\circ} \mathrm{C}, 30 \mathrm{~s}$ at $58^{\circ} \mathrm{C}, 20 \mathrm{~s}$ at $72{ }^{\circ} \mathrm{C}$ ) and a final elongation step of $10 \mathrm{~min}$ at $72{ }^{\circ} \mathrm{C}$. Each PCR reaction consisted of $1 \mu \mathrm{L}$ of template DNA (100 ng), $12.5 \mu \mathrm{L}$ of MyFi ${ }^{\mathrm{TM}}$ Mix (Meridian Bioscience), $900 \mathrm{nM}$ for both primers (Hdc1 plus Hdc2) and nuclease-free molecular biology grade water to reach the final volume of $25 \mu \mathrm{L}$. The results were checked by electrophoresis, the HyperLadder ${ }^{\mathrm{TM}} 100$ bp (Meridian Bioscence) was used as molecular weight standard.

\subsubsection{Antimicrobial activity of lactic acid bacteria isolates}

The determination of the antimicrobial activity of the 60 lactic acid bacteria strains isolated from fish sausage samples was performed by following the Agar Well Diffusion Assay (AWDA), described by Parente et al. (1995). Briefly, molten BHI soft agar (0.75\% agar) (VWR Prolabo Chemicals) was inoculated (2\%) with the indicator microorganism Listeria innocua. Twenty $\mathrm{mL}$ of the inoculated medium were poured into $90 \mathrm{~mm}$ Petri dish and left to solidify. A cone of a $200 \mu \mathrm{L}$ tip was utilized to create wells of $\sim 50 \mu \mathrm{L}$ capacity on BHI soft agar. Previously, lactic acid bacteria strains were sub-cultured twice on MRS broth at $37^{\circ} \mathrm{C}$ for $48 \mathrm{~h}$. The broth cultures were then added with $0.1 \mathrm{~N} \mathrm{NaOH}$ solution to reach $\mathrm{pH} 7.0$ in order to neutralise the organic acids produced during the bacterial growth. A filtration step on sterile PES membrane filter of $0.22 \mu \mathrm{m}$ pore size (Laboindustria S.p.A., Padova, Italy) followed. For each lactic acid bacteria strain, 4 wells were formed on BHI soft agar, each containing: (i) $50 \mu \mathrm{L}$ of the sub-cultured suspension; (ii) $50 \mu \mathrm{L}$ of the neutralised suspension adjusted to $\mathrm{pH} 7.0$; (iii) $50 \mu \mathrm{L}$ of the filtered neutralised suspension; (iv) $50 \mu \mathrm{L}$ of sterilised water as a negative control. Afterwards, the Petri dishes were incubated at $37^{\circ} \mathrm{C}$ for $24 \mathrm{~h}$ and were examined for the presence of zones of inhibition. In the case of positive results (presence of inhibition halo), 3 spots of $5 \mu \mathrm{L}$ each of pepsin (Fluka ${ }^{\mathrm{TM}}$, Honeywell, Morristown, USA), trypsin (Fluka ${ }^{\mathrm{TM}}$ ) or Pronase (Merck KGaA, Darmstadt, Germany) were set along the circumference of the inhibition zone to evaluate the protein nature of the antimicrobial. The Petri dishes were further incubated at the same conditions. The antimicrobial activity of lactic acid bacteria strains due to the synthesis of bacteriocins was confirmed by the formation of crescents.

\subsubsection{EPS production of lactic acid bacteria isolates}

The 60 lactic acid bacteria strains were screened for EPS production, based on the method already reported by Hilbig et al. (2019) with some modifications. In more detail, lactic acid bacteria isolates were retrieved from cryo-protective suspensions and sub-cultured twice on MRS broth at $37^{\circ} \mathrm{C}$ for $48 \mathrm{~h}$. The EPS production was visually observed by adding aliquots of $5 \mu \mathrm{L}$ for each bacterial strain on the following media: (i) MRS agar supplemented with sucrose $\left(80 \mathrm{~g} \mathrm{~L}^{-1}\right)$ to promote the synthesis of homopolysaccharides (HoPS); MRS agar supplemented with yeast extract $\left(10 \mathrm{~g} \mathrm{~L}^{-1}\right)$, meat extract $\left(10 \mathrm{~g} \mathrm{~L}^{-1}\right)$, galactose $\left(20 \mathrm{~g} \mathrm{~L}^{-1}\right)$ and lactose $\left(20 \mathrm{~g} \mathrm{~L}^{-1}\right)$ to promote the synthesis of heteropolysaccharides (HePS). After an incubation period of $48 \mathrm{~h}$ at $30{ }^{\circ} \mathrm{C}$, the colonies were classified as positive whenever presenting a mucoid aspect (visible shiny and slimy appearance) or a ropy consistence (able to produce detectable filaments by using a sterile toothpick). The positive strains were additionally tested to confirm EPS production under stressed conditions on RSM agar, containing the following ingredients: meat extract $\left(100 \mathrm{~g} \mathrm{~L}^{-1}\right)$, nitrite curing salt $\left(0.5 \% \mathrm{w} / \mathrm{w} \mathrm{NaNO}_{3}\right.$ in $\left.\mathrm{NaCl}\right)\left(30 \mathrm{~g} \mathrm{~L}^{-1}\right)$, agar $\left(15 \mathrm{~g} \mathrm{~L}^{-1}\right)$, tween $80\left(1 \mathrm{~g} \mathrm{~L}^{-1}\right)$, sodium ascorbate $\left(0.6 \mathrm{~g} \mathrm{~L}^{-1}\right)$ and lactic acid to reach a final $\mathrm{pH}$ of 5.8; moreover, sucrose $\left(80 \mathrm{~g} \mathrm{~L}^{-1}\right)$ or glucose $\left(20 \mathrm{~g} \mathrm{~L}^{-1}\right)$, galactose $\left(20 \mathrm{~g} \mathrm{~L}^{-1}\right)$ and lactose $\left(20 \mathrm{~g} \mathrm{~L}^{-1}\right)$ were added depending on the previous results. The positive phenotypes were confirmed after an incubation period of $120 \mathrm{~h}$ at $20^{\circ} \mathrm{C}$. For each strain, three spots were formed on the same plate and the analyses were conducted in duplicate.

\subsubsection{Detection of EPS-related genes of lactic acid bacteria isolates}

The presence of EPS-related genes on lactic acid bacteria strains was further investigated, as described by Milanović et al. (2020). In more detail, the EPS-related genes include eps $A$, eps $B$, epsD/E and epsEFG, involved in HePS biosynthesis, and gtf and lev, involved in HoPS biosynthesis. The extracted DNAs of lactic acid bacteria strains were amplified by PCR in My Cycler Thermal Cycler (BioRad Laboratories) following the conditions and primer pairs detailed by Palomba et al. (2012) and reported in the Supplementary Table 1. Each PCR reaction consisted of $3 \mu \mathrm{L}$ of template DNA (300 ng), $25 \mu \mathrm{L}$ of MyFi ${ }^{\mathrm{TM}}$ Mix (Meridian Bioscience), 
$1 \mu \mathrm{M}$ of each primer and nuclease-free molecular biology grade water to reach the final volume of $50 \mu \mathrm{L}$. Few randomly selected amplicons testing positive after observation by electrophoresis were shipped to Genewiz (Takaley, UK) for their purification and sequencing to confirm the reaction specificity for each EPS-related gene. The resulting sequences were subjected to alignment with similar deposited in the GenBank database by BLAST search (http://www.ncbi.nlm.nih.gov/).

\section{Results}

\subsection{Physico-chemical measurements}

The results of the physico-chemical measurements of the fermented fish sausage samples are reported in Table 1.

$\mathrm{pH}$ values were comprised between $5.51 \pm 0.01$ (sample FS9) and $5.87 \pm 0.04$ (sample FS2) with no significant statistical differences among batches.

$\mathrm{a}_{\mathrm{w}}$ values ranged between $0.92 \pm 0.01$ (sample FS9) and $0.94 \pm 0.01$ (samples FS4, FS5 and FS6). The statical analysis showed a significant difference between batches 2 and 3 .

The results of the TTA were characterized by values between $21.8 \pm 2.4$ (sample FS4) and $27.8 \pm 0.9$ (FS8) $\mathrm{mL}$ of a $0.1 \mathrm{~N} \mathrm{NaOH}$ solution. A higher mean value was reported for batch 2, whereas batches 1 and 3 showed the lowest mean values.

Regarding lactic acid content, high concentrations were generally detected in fish sausage samples. In more detail, lactic acid values of fish sausages were comprised between $1.336 \pm 0.021$ (sample FS1) and $2.368 \pm$

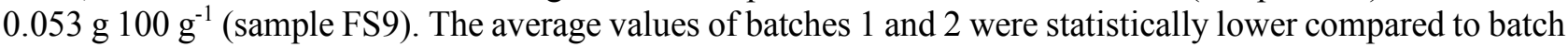
3.

The acetic acid was detected in all the samples, with lowest values comprised between $0.027 \pm 0.001$ (sample

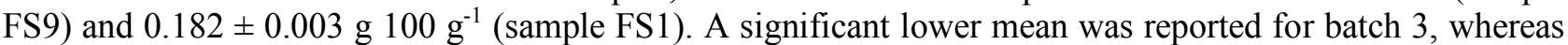
batch 1 was characterised by the highest mean value.

Finally, the histamine content was highly variable among fish sausage samples; in fact, the values ranged from $<4.2 \mathrm{mg} \mathrm{Kg}^{-1}$ (sample FS8) to $299.6 \pm 13.5 \mathrm{mg} \mathrm{Kg}^{-1}$ (sample FS1). The highest mean value was detected in samples from batch 1 .

\subsection{Microbiological analyses}

The results of the microbiological viable counts of the fermented fish sausage samples are reported in Table 2 . Presumptive lactic acid bacteria showed the highest viable counts, varying from $7.57 \pm 0.01$ (sample FS9) to $9.12 \pm 0.03 \mathrm{Log} \mathrm{cfu}^{-1}$ (sample FS4). The statistical analysis showed significant differences among all the batches.

Regarding enterococci, counts were comprised from $<1.00$ (samples of batch 3) and $4.96 \pm 0.03 \mathrm{Log} \mathrm{cfu} \mathrm{g}^{-1}$ (sample FS1). Batch 1 showed the highest mean value, whereas batch 3 the lowest.

As for coagulase-negative staphylococci, counts between $2.64 \pm 0.06$ (sample FS8) and $5.87 \pm 0.04$ (sample FS2) Log cfu g ${ }^{-1}$ were detected. The lowest average count was reported for batch 3, whereas batches 1 and 2 showed the highest average values.

The results of Enterobacteriaceae and Pseudomonadaceae viable counts showed the same trend; in fact, both microbial groups were $<1 \operatorname{Log~cfu~g}^{-1}$ in batches 1 and 3, whereas Enterobacteriaceae and Pseudomonadaceae mean values of batch 2 were statistically higher, reaching up to $4.45 \pm 0.29$ (sample FS5) and $5.16 \pm 0.05 \mathrm{Log}$ cfu $\mathrm{g}^{-1}$ (sample FS5), respectively.

Finally, eumycete counts ranged between $4.24 \pm 0.08$ (sample FS5) and 5.59 $\pm 0.05 \mathrm{Log} \mathrm{cfu} \mathrm{g}^{-1}$ (FS7). Batch 2 was characterized by the lowest average value, whereas those of batches 1 and 3 were statistically higher.

\subsection{Microbiota composition}

\subsubsection{Bacterial composition}

After sequencing and quality filtering, a total of 186,395 reads were used for the downstream analysis with an average of 10,355 sequence/sample and a sample coverage of $99 \%$. The alpha diversity analysis showed the lowest level of complexity and a minor number of observations in samples belonging to batch 1, followed by batches 3 and 2 (Kruskal-Wallis $P<0.001$ ). Bacterial composition displayed the highest frequency of 
Latilactobacillus sakei (90, 69 and 79\% in batch 1, 2 and 3, respectively), Clostridium (3, 9 and 6\% in batch 1,2 and 3, respectively), Latilactobacillus curvatus (1, 4 and 3\% in batch 1, 2 and 3, respectively), Peptostreptococcus (1, 5 and 4\% in batch 1, 2 and 3, respectively) and Bacteroides (0.5, 3 and 2\% in batch 1, 2 and 3, respectively) (Fig. 1). In addition, several minor ASVs less than $1 \%$ of the relative frequency were shared between datasets. From the beta diversity calculation, based on the weight unifrac distance matrix (Fig. 2, panel A), a clear separation of the samples depending on the different batches was observed. The analysis of the frequency difference of the Amplicon Sequence Variants (ASVs) showed that Latilactobacillus sakei and Staphylococcus succinus were mainly associated with batch 1, Turicibacter with batch 3 and the other ASVs with batch 2 (FDR $<0.05)$.

\subsubsection{Eumycetic composition}

After sequencing and quality filtering, a total of 440,962 reads were used for the downstream analysis with an average of 24,498 sequence/sample and a sample coverage of $99 \%$. The alpha diversity analysis showed the lowest level of complexity and a minor number of observations in samples belonging to batch 1, whereas no differences were observed between batches 2 and 3 (Kruskal-Wallis $P<0.001$ ). Eumycetic composition displayed the highest frequency of Kurtzmaniella zeylanoides (54, 34 and 49\% in batch 1, 2 and 3, respectively), Rhodotorula mucilaginosa (18, 46 and 29\% in batch 1, 2 and 3, respectively), Debaryomyces hansenii (17, 4 and 11\%), Galactomyces (5, 9 and 7\% in batch 1, 2 and 3, respectively) and Galactomyces geotrichum (3, 5 and $4 \%$ in batch 1, 2 and 3, respectively). In addition, several minor ASVs less than $1 \%$ of the relative frequency were shared between all the datasets. By plotting the weight unifrac distance matrix (Fig. 2, panel B), no clear separation of the samples was observed. Moreover, Debaryomyces hansenii was the only ASVs discriminating the samples, as it was mainly associated with batch 3 (FDR < 0.05).

\subsection{Detection of histidine decarboxylases-codifying genes in food matrix}

The standard curve of the qPCR performed on the homogenates of fish sausage samples to detect the $h d c A$ gene of Gram-positive bacteria showed an efficiency of 0.96 and a $\mathrm{R}^{2}$ of 0.998 . The detection limit was $\sim 1$ Log gene copies of cells per reaction. The results indicated that the copy number of $h d c A$ gene was below the detection limit in all the fish sausage samples.

On the other hand, the standard curve of the qPCR performed to detect the $h d c$ gene of Gram-negative bacteria showed an efficiency of XXX and a $\mathrm{R}^{2}$ of XXX. The detection limit was $\sim \mathrm{XXX}$ Log gene copies of cells per reaction. Interestingly, the $h d c$ gene was not detected in batches 1 and 3, whereas it was detected in batch 2 . In more detail, samples from batch 2 showed $h d c$ gene abundances of $5.20 \pm 0.21$ (sample FS4), $5.50 \pm 0.26$ (sample FS5) and 5.49 \pm 0.18 Log cells/gene copies $\mathrm{g}^{-1}$ (sample FS6).

\subsection{Characterization of the dominant $L A B$}

The alignment results of $16 \mathrm{~S}$ rRNA sequences obtained from the 60 lactic acid bacteria isolated from the fermented fish sausage under study are listed in Table 3. The BLAST search allowed to achieve an unambiguous identification for all the tested isolates. In detail, L. curvatus was the most frequently isolated species ( 38 isolates), followed by $L$. sakei ( 22 isolates). The lactic acid bacteria species were equally distributed among samples, apart for FS4 (batch 2) and FS9 (batch 3) isolates exclusively belonging to the species $L$. curvatus.

Lactic acid bacteria fingerprints obtained by REP-PCR were used to build a PCoA, as a function of the batch (Fig. 3). Each batch displayed the presence of similar L. sakei REP-biotype, whereas some strains belonging to batch 1 and 2 were from the same biotype (Fig. 3, panel a). Regarding L. curvatus, strains belonging to batch 2 were well separated from those isolated from batch 1 and 3 (Fig. 1 panel b), whereas strains belonging to batches 1 and 3 showed the highest degree of similarity.

Regarding the PCR to detect the presence of $h d c A$ gene of Gram-positive bacteria on the 60 lactic acid bacteria isolates, the electrophoresis showed that no isolate was positive for the target gene.

The results of AWDA showed that none of the isolates exerted an inhibitory activity against L. innocua. In fact, the limited cases of zones of inhibition were attributed to the acidity of the sub-cultured suspensions, since the formation of crescents after the addition of pepsin, tripsin and Pronase did not occur.

The results of the screening of the 60 lactic acid bacteria isolates for the EPS production are reported in Table 3. In particular, 39 isolates showed sucrose dependent EPS production through the formation of mucoid 
colonies. The EPS production, presumably HoPS, of such isolates was confirmed under stressed conditions on RSM agar. On the contrary, the sucrose independent EPS production was not registered in any case.

The screening of the isolates for the occurrence of EPS-related genes highlighted the presence of genes involved in HePS biosynthesis. In detail, 56 isolates harboured the gene epsD/E, involved in the glycosyltransferase synthesis, whereas 37 strains resulted positive for the presence of epsA gene, involved in EPS regulation. Such findings were confirmed by sequencing and alignment with similar deposited sequences in the GenBank database of randomly selected positive amplicons. The 60 lactic acid bacteria isolates showed the absence of the other EPS-related genes, including those involved in HoPS production.

\section{Discussion}

Italian tradition in charcuterie dates back to the 12th century, when many fermented meat products, mainly based on the use of swine meat, were developed. Based on traditional recipes and processes of fermented meat products, the fermented fish sausages investigated in the present study were produced. The obtained endproduct represents a culinary uniqueness whose microbiota has never been investigated before.

Interestingly, the overall data collected on the analysed fish sausages highlighted many physico-chemical and microbiological traits that were more similar to those of fermented meat sausages rather than fermented seafood products.

As far as $\mathrm{pH}$ values are concerned, an overall homogeneity was observed among the analysed batches, thus attesting a high level of standardization of the process. The detected values were almost comparable with those reported by $\mathrm{Li}$ et al. (2021) in naturally fermented tilapia sausages that showed values comprised between 5 and 5.2 after 30 days fermentation. Conversely, $\mathrm{pH}$ values of the analysed samples were higher than those reported by Zhao et al. (2021) and Zhang et al. (2013) in naturally fermented tilapia sausages and fermented silver carp sausages, respectively, attesting at about 4.5 after 30 days fermentation. It is noteworthy that, in fermented foods, $\mathrm{pH}$ reduction represents one of the main hurdles towards spoilage and pathogenic bacteria, thus contributing to obtain a safe food. Generally, in meat sausages, a deacidification occurs at the end of fermentation, with $\mathrm{pH}$ increase at about 5.5; hence, it is likely that a similar process could also have occurred in the analysed fish sausages. More research is needed to investigate $\mathrm{pH}$ dynamics on the studied fish sausages for which it is recommended that $\mathrm{pH}$ lower than 4.4 is reached during fermentation.

Regarding $\mathrm{a}_{\mathrm{w}}$, the detected values were notably higher than those detected by $\mathrm{Hu}$ et al. (2008) in fermented silver carp sausages, which ranged between 0.86 and 0.82 after 48 days fermentation. $\mathrm{A}_{\mathrm{w}}$, coupled with $\mathrm{pH}$, contributes to create a hostile environment for the multiplication of some unwanted microorganisms and therefore its monitoring is particularly useful.

The high values of lactic acid detected in the analysed samples attested the occurrence of a robust microbial metabolic activity from lactic acid bacteria with a prevalent homofermentative or facultative heterofermentative metabolism. Production of organic acids contributes to $\mathrm{pH}$ decrease and confers a pleasant taste to the end-product. High lactic acid concentration was also observed by $\mathrm{Hu}$ et al. (2008) in fermented silver carp sausages after 48 days fermentation.

In the analysed samples high loads of viable microorganisms were detected.

As for presumptive lactic acid bacteria, the counts were slightly lower than those detected by Zhang et al.

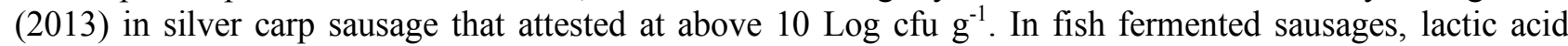
bacteria catabolize pentose or hexose during fermentation, leading to the production of organic acids, including lactic and acetic acid (Zhou et al., 2021). Moreover, fish muscle proteins are progressively hydrolysed during fermentation by both bacterial and fish proteinases (Udomsil et al., 2010). Among these enzymes, aminopeptidases convert peptides and/or oligopeptides to amino acids that further serve as a precursor for flavour formation (Udomsil et al., 2010). The high loads of lactic acid bacteria detected in the studied samples attest the high adaptation of such a microbial group to the fermented fish sausages, thus confirming their pivotal role in obtaining the end-product. Other studies reported that the lactic acid bacteria, especially Pediococcus and Lactococcus, play a key role in the definition of physico-chemical traits in naturally fermented fish sausages (Li et al., 2021; Zhao et al. 2021).

Regarding enterococci, found with variable loads in the analysed samples, species belonging to such microbial group have already been detected by Li et al. (2021) and Zhao et al. (2021) in naturally fermented tilapia sausages, thus attesting their adaptation to this specific food matrix. Zhang et al. (2013) reported that enterococci could be responsible of accumulation of tyramine in fermented fish sausages; interestingly, Zhao et al. (2021) recently discovered a significant contribution of enterococci in the accumulation of biogenic amines in naturally fermented tilapia sausages. 
As for coagulase negative staphylococci, to the author's knowledge a lack of information is available in the scientific literature for further comparison of data. However, species of coagulase negative Staphylococcus have already been detected in different fermented fish preparations (Khusro et al., 2017). Interestingly, probiotic species of staphylococci were also isolated from fermented fish by Borah et al. (2016), thus suggesting the need for further in depth regarding this microbial group in the samples under study.

In the analysed samples, high counts of Enterobacteriaceae and Pseudomonadaceae were also detected. It is noteworthy that both these two families of bacteria encompass potential human pathogens or spoilage microorganisms that, in fermented foods, are inhibited by fermentation metabolites (e.g., organic acids, bacteriocins). Moreover, Enterobacteriaceae play a pivotal role in the formation of biogenic amines since it is known that Escherichia coli can adapt its metabolism by self-regulating low $\mathrm{pH}$ values and lysine-containing environments by decarboxylating lysine in order to generate cadaverine for neutralizing excessive $\mathrm{H}+$ in the system (Meng et al., 2022). The presence of Pseudomonadaceae is not surprising since members belonging to this family have already been detected in fermented fish products as jeotgal, a Korean traditional fermented fish sauce, myeolchijeot (anchovy) (Singh et al., 2018), as well as in naturally fermented tilapia (Zhao et al., 2021) and silver carp sausages, in this latter with counts attesting at about $5 \mathrm{Log}$ cfu/g after $48 \mathrm{~h}$ fermentation (Zhang et al., 2013). The presence of Enterobacteriaceae and Pseudomonadaceae in the fermented fish sausages suggests a possible lack of acidification during fermentation.

Regarding eumycetes, the counts detected in the analysed samples were in accordance with those reported by Zhang et al. (2013) in spontaneously fermented silver carp sausages and in plaa-som, a Thai fermented fish (Saithong et al., 2010). It can be hypothesized that, similarly to meat sausages, yeasts could exert the following effects: i) protective role against lipid oxidation; ii) allow proper drying by protecting the sausage against fluctuation in humidity; iii) release peptides, free amino acids and free fatty acids by lactic acid metabolization (Belleggia et al., 2020).

In order to obtain a more precise overview into the microbiota involved in the fermentation of the studied fermented fish sausages, a metataxonomic analysis, based on the study of microbial DNA, was coupled with the culture-dependent approach. In this context, amplicon sequencing represents by far the most used approach for metataxonomic studies (Parente et al., 2020).

In the present study, the metataxonomic approach allowed major and minor microbial species to be detected. In more detail, among bacteria, L. sakei represented the dominant species at the end of fermentation in all the analysed samples. Although this pro-technological lactic acid bacterium is commonly detected in fermented meat sausages as one of the fermentation-driving species (Aquilanti et al., 2016), to the authors' knowledge, its occurrence in fermented fish sausages is uncommon. Interestingly, L. sakei has already been detected as major species in rakfisk, produced in Northern Europe from salmonid freshwater fish (Skåra et al., 2015), and as minor species in jeotgal (Jung et al., 2018). Moreover, L. sakei has been exploited as starter culture for the reduction of biogenic amines accumulation in som-fug, a Thai traditional fermented fish sausage (Kongkiattikajorn, 2015). The homolactic fermentation of hexoses, carried out by L. sakei, produces lactic acid via the glycolytic pathway, whereas acetic acid is produced through heterolactic fermentation of pentoses. Moreover, L. sakei produces proteinases and aminopeptidases which degrade muscle proteins, using free amino acids and nucleotides as source of energy (Belleggia et al., 2020b). L. sakei is also able to use glucose, fructose and different hexoses as primary energy sources (Ferrocino et al., 2018).

In the analysed samples, L. curvatus was detected as minority species. Also this lactic acid bacterium is one of the most detected in fermented meat sausages being able to hydrolyse muscle proteins (Casaburi et al., 2016; Sun et al., 2019). Interestingly, L. curvatus has recently been isolated from Korean traditional fermented seafood, showing potential cholesterol reduction effect (Kim et al., 2021). To the authors' knowledge, there is a lack of data regarding the presence of $L$. curvatus in fermented fish sausages.

It is noteworthy that both $L$. sakei and $L$. curvatus are able to produce EPS that could interact with food matrix and with other beneficial microorganisms. Indeed, it is known that EPS produced by lactic acid bacteria could improve taste, texture and stability of food products (Wang et al., 2019). Moreover, $\alpha$-D-glucan and EPS containing glucose and mannose produced by Lactobacillus spp. showed significant prebiotic activity to increase the growth of probiotic bacteria (Wang et al., 2019). EPS produced by lactic acid bacteria could also exerts several health-promoting effects, such as anti-inflammatory, antioxidant and antibiofilm activities (Wang et al., 2019).

L. sakei and L. curvatus are also able to produce bacteriocins that could improve the safety of fermented foods, being active against foodborne human pathogens. Bacteriocins are bioactive antimicrobial peptides that are synthesized in the ribosome of numerous bacteria and released extracellularly (Zau et al., 2018). In more detail, sakacin produced by L. sakei, due to its antimicrobial effectiveness (e.g., against Listeria monocytogenes), 
possesses a significant potential as biopreservative (Mapelli et al., 2019), whereas curvaticin 13, a bacteriocin produced by a $L$. curvatus strain, proved from long time to have a bactericidal effect against $L$. monocytogenes (Bouttefroy and Millière, 2000).

Based on these premises, the 60 isolates of lactic acid bacteria (22 isolates of $L$. sakei and 38 of L. curvatus) were subjected to in vitro characterization of some pro-technological features. In more detail, the production of bacteriocins (sakacin and curvaticin), the production of EPS and the detection of EPS-related genes were assayed with the future goal to obtain effective starter cultures to be used for process standardization. Indeed, as reported by Cruxen et al. (2019), the most promising microorganisms utilized as starter cultures are those isolated from native microbiota of artisanal/local products.

Isolates were also tested for the absence of the $h d c A$ gene, that codifies for histidine decarboxylase enzyme and could potentially lead to histamine production in the food matrix.

Among the isolates tested for the production of saccharose-dependent EPS, 39 out of 60 showed the formation of mucoid colonies. Interestingly, Hilbig et al. (2019) reported that exopolysaccharide-producing lactic acid bacteria can positively affect spreadability, texture, and taste of fermented sausages. Hilbig et al. (2019) also suggested that the initial sugar content of the meat batter as well as the addition of different mixtures of saccharose and glucose should be evaluated in order to maximize the production of EPS. It is noteworthy that, as reported by Almansoory et al. (2020), $\mathrm{pH}$, carbon and nitrogen sources, and inorganic ions strongly affect the production of EPS by lactic acid bacteria. Hence, although the isolates tested in the present study showed the presence of some of the genes involved in the production of heteropolysaccharides, not all the isolates were able to produce mucoid colonies on agar plates, being likely influenced by the above-mentioned parameters.

It is known that the production of bacteriocins is strain specific (Zau et al., 2018); for example, Lacticaseibacillus paracasei CNCM I5369 strain carries five genes (orf010, orf012, orf023, orf030 and orf038) coding for class II bacteriocins (Belguesmia et al., 2020). Regarding the screening of isolates for the production of bacteriocins, it is likely that no isolate possessed the genetic determinants for bacteriocin synthesis, since no $L$. sakei or $L$. curvaus exerted a bactericidal effect against $L$. innocua, hence, data will not be further discussed.

Lactic acid bacteria isolates obtained in the present study were negative for the presence of the $h d c A$ gene of Gram-positive bacteria; this finding agrees with the absence of the same gene in the food matrix and supports their potential use as starter cultures in driven fermentation processes.

It is noteworthy that occurrence of biogenic amines in fish-based foods represents one of the main health issues related to this specific fermented food (Belleggia et al., 2021). Among biogenic amines, histamine is produced by the degradation of the amino acid histidine via bacterial decarboxylation; in more detail, this reaction is determined by the activity of the enzyme histidine decarboxylase encoded by a gene cluster that includes the $h d c A$ gene (Diaz et al., 2016). The $h d c A$ gene products belong to the pyruvoyl-dependent histidine decarboxylases of Gram-positive bacteria, whereas Gram-negative bacteria use a different type of histidine decarboxylases that is pyridoxal phosphate dependent (Lucas et al., 2005).

In the analysed samples, variable levels of histamine were detected, thus suggesting the presence of microbial strains carrying histidine decarboxylases-codifying genes in the raw materials. In fact, the detected gene copies of the $h d c$ gene of Gram-negative bacteria in batch 2 might be correlated with the histamine levels detected in the same batch. It is likely that the detected gene copies could have been carried by members of the Enterobacteriaceae family, however, further research is needed to better clarify the origin of the detected gene. On the other hand, the histamine content detected in batches 1 and 3 remains to be clarified. Although the qPCR assays prove to be valid and rapid for a proper evaluation of histamine risk in fermented foods, the detection limit of $\sim 4 \mathrm{Log}$ cells/gene copies $\mathrm{g}^{-1}$ appears unsatisfactory for certain applications. Moreover, as reported by Bjornsdottir-Butler et al. (2011), the primers used in the present study for the $h d c$ gene of Gramnegative bacteria are suitable to detect high-histamine producing bacteria but exclude low- or non-detectable histamine producing bacteria. Although the qPCR assays provide quick and sound results in cases of high detection limits, its integration with other methods, in order to avoid the risk of histamine formation and scombroid poisoning, could be suggested.

Among biogenic amines, histamine is mostly implicated in food poisonings with potential health risks for consumers. In order to protect the health of consumers, in the European Union, the Commission Regulation (EC) 2073/2005 lays down food safety criteria for histamine in fishery products obtained from fish species associated with a high amount of histidine, between $100 \mathrm{mg} / \mathrm{Kg}$ and $200 \mathrm{mg} / \mathrm{Kg}$. The same Regulation also establishes limits of histamine between $200 \mathrm{mg} / \mathrm{Kg}$ and $400 \mathrm{mg} / \mathrm{Kg}$ for fishery products subjected to enzyme maturation treatment in brine. Moreover, according to the United States Food and Drug Administration (FDA) (2001), histamine levels of fishery products should not exceed $50 \mathrm{mg} / \mathrm{Kg}$, whereas a value over $500 \mathrm{mg} / \mathrm{Kg}$ 
represents a possible risk for the health consumers (Belleggia et al., 2021). In the present study, only samples from one production batch showed high values of histamine, although, according to Commission Regulation (EC) 2073/2005, fermented fish sausages do not fall into food categories that have to be monitored for histamine content. It is noteworthy that, according to the European Food Safety Authority (EFSA) BIOHAZ Panel (2011), the evaluation of histamine risk in foods requires a case-by-case approach, since each food type is characterized by specific formulations and process parameters. Of note that, in acidic fermented foods, although the decrease in $\mathrm{pH}$ is recognized as a crucial factor to reduce the multiplication of contaminating microbiota, such phenomenon can in turn promote decarboxylation reactions carried out by surviving microorganisms in response to acidic stress (Vidal-Carou et al. 2007).

Finally, metataxonomic analysis allowed major and minor eumycetes species to be identified, to the authors' knowledge, eumycetes in fermented fish products are less investigated and further comparison of data is difficult to be performed. In the present study $K$. zeylanoides, $R$. mucilaginosa, and D. hansenii constituted the dominant species. Interestingly, all these species are constantly detected in fermented meat sausages, thus suggesting their adaptation also to fermented fish sausages where they could presumably exert similar metabolic activities to those performed in meat-based matrices.

As for K. zeylanoides (formerly known to as Candida zeylanoides), this yeast has already been found in Suan $y u$, a Chinese traditional fermented fish (Zang et al., 2018), in traditional Icelandic fermented fish (Osimani et al., 2019), and in different fermented sausages produced in Southern Italy (Belleggia et al., 2020). Moreover, members belonging to Candida species were detected in ethnic dried and salted or fermented fish products of Nepal and Northeast India, as bordia, gnuchi, lashim, hentak, karati, sidra, and ngari (Thapa, 2016).

Regarding R. mucilaginosa, this yeast species is commonly part of the minor fraction of the mycobiota of fermented sausages (Belleggia et al., 2020). Interestingly, Li et al. (2010) isolated $R$. mucilaginosa as marinederived yeast from surface of marine fish, thus suggesting the adaptation of such yeast to marine environment and explaining its presence in the fish flesh used for the production of the fermented sausages under study.

$D$. hansenii represents one of the key yeast species detected in the fungal community of fermented meat sausages (Belleggia et al., 2020). D. hansenii is a halotolerant, lipolytic yeast able to hydrolyze muscle proteins, thus contributing to the definition of the sensory traits of fermented sausages. Moreover, the metabolic activity of this foodborne yeast leads to the increase of ammonia concentration and the decrease of lactate and acetate content (Belleggia et al., 2020). Interestingly, D. hansenii was isolated from the gut of rainbow trout reared in fresh water (Reyes-Becerril et al., 2008), hence, it is likely that the presence of such yeast species in the fermented sausages under study could be ascribed to cross-contamination between the gut content and the flesh of fish during slaughtering.

\section{Conclusion}

The data overall collected allowed a first picture of the microbiota of novel fermented fish sausages to be drawn. Regarding the microbiota composition, many bacteria and eumycetes commonly associated with fermented meat sausages were detected, thus suggesting their adaptation to a previously unexplored niche where $L$. sakei was surprisingly found as dominant species in all the analysed batches. As for lactic acid bacteria, none of the isolates showed the presence of genes for the decarboxylation of histidine, thus suggesting their suitability for further testing as potential starter cultures. Interestingly, the EPS production capability showed by many lactic acid bacteria isolates could represent a starting point for their future selection as adjunct cultures to improve texture and sensory traits of the fermented fish sausages under study. Further research is needed to understand microbial and physico-chemical changes occurring during fermentation of fish sausages, and to verify the in vivo performance of the isolates in the fish flesh. A further in-depth is also recommended to shed a light into bacteria-related histamine production dynamics.

\section{Acknowledgments}

The authors wish to thank Offishina, Via Armellini 74, 73046, Matino (LE), Italy, that kindly provided "Pescatorino" fermented fish sausages.

\section{References}

Y. Belguesmia, K. Bendjeddou, I. Kempf, R. Boukherroub, D. Drider, Heterologous biosynthesis of five new class II bacteriocins from Lactobacillus paracasei CNCM I-5369 with antagonistic activity against 
pathogenic Escherichia coli strains, Front. Microbiol. $11 \quad$ (2020), doi:http://dx.doi.org/10.3389/fmicb.2020.01198.

Martha Reyes-Becerril, Dariel Tovar-Ramírez, Felipe Ascencio-Valle, Roberto Civera-Cerecedo, Vicente Gracia-López, Valérie Barbosa-Solomieu, Effects of dietary live yeast Debaryomyces hansenii on the immune and antioxidant system in juvenile leopard grouper Mycteroperca rosacea exposed to stress, Aquaculture, Volume 280, Issues 1-4, 2008, Pages 39-44, https://doi.org/10.1016/j.aquaculture.2008.03.056.

Mei Li, Guang-Lei Liu, Zhe Chi, Zhen-Ming Chi, Single cell oil production from hydrolysate of cassava starch by marine-derived yeast Rhodotorula mucilaginosa TJY15a, Biomass and Bioenergy, Volume 34, Issue 1, 2010, Pages 101-107, https://doi.org/10.1016/j.biombioe.2009.10.005.

Namrata Thapa, Ethnic fermented and preserved fish products of India and Nepal, Journal of Ethnic Foods, Volume 3, Issue 1, 2016, Pages 69-77, https://doi.org/10.1016/j.jef.2016.02.003.

Jinhong Zang, Yanshun Xu, Wenshui Xia, Dawei Yu, Pei Gao, Qixing Jiang, Fang Yang, Dynamics and diversity of microbial community succession during fermentation of Suan yu, a Chinese traditional fermented fish, determined by high throughput sequencing, Food Research International, Volume 111, 2018, Pages 565-573, https://doi.org/10.1016/j.foodres.2018.05.076.

Osimani, A., Ferrocino, I., Agnolucci, M., Cocolin, L., Giovannetti, M., Cristani, C., Palla, M., Milanović, V., Roncolini, A., Sabbatini, R., Garofalo, C., Clementi, F., Cardinali, F., Petruzzelli, A., Gabucci, C., Tonucci, F., Aquilanti, L., 2019. Unveiling hákarl: a study of the microbiota of the traditional Icelandic fermented fish. Food Microbiol. 82, 560-572.

EFSA Panel on Biological Hazards (BIOHAZ) 2011. Scientific Opinion on Scientific Opinion on risk based control of biogenic amine formation in fermented foods. EFSA J. 9(10):2393. doi: $10.2903 /$ j.efsa. 2011.2393

Food and Drug Administration (FDA) 2001. Scombrotoxin (histamine) formation. In: Food and Drug Administration, editor. Fish and fishery products hazards and controls guidance. 3rd ed. Washington, DC, USA (CFSAN, Office of Seafood). pp 230-257.

Regulation (EC) No. 2073/2005 of the European Parliament and the Council of 15 November 2005 on microbiological criteria for foodstuffs 2005. Off J Eur Union. http://eurlex.europa.eu/LexUriServ/LexUriServ.do?uri=OJ:L:2005:338:0001:0026:EN:PDF

Vidal-Carou MC, Latorre-Moratalla ML, Veciana-Nogués MT, Bover-Cid S 2007. Biogenic amines: risks and control. In: F Todrà, YH Hui, I Astiasarán, Wai-Kit Nip, JG Sebranek, ETF

Jiong Zou, Han Jiang, Hui Cheng, Jiehong Fang, Guangrong Huang, Strategies for screening, purification and characterization of bacteriocins, International Journal of Biological Macromolecules, Volume 117, 2018, Pages 781-789, https://doi.org/10.1016/j.ijbiomac.2018.05.233.

Jonas Hilbig, Julia Gisder, Roman M. Prechtl, Kurt Herrmann, Jochen Weiss, Myriam Loeffler, Influence of exopolysaccharide-producing lactic acid bacteria on the spreadability of fat-reduced raw fermented sausages (Teewurst),

Food Hydrocolloids, Volume 93, 2019, Pages 422-431, https://doi.org/10.1016/j.foodhyd.2019.01.056.

Anne Bouttefroy, Jean-Bernard Millière, Nisin-curvaticin 13 combinations for avoiding the regrowth of bacteriocin resistant cells of Listeria monocytogenes ATCC 15313, International Journal of Food Microbiology, Volume 62, Issues 1-2, 2000, Pages 65-75, https://doi.org/10.1016/S0168-1605(00)00372-X.

Chiara Mapelli, Alberto Barbiroli, Stefano De Benedetti, Alida Musatti, Manuela Rollini, Antilisterial Bacteriocins for Food Security: The Case of Sakacin A, Editor(s): Pasquale Ferranti, Elliot M. Berry, Jock R. 
Anderson, Encyclopedia of Food Security and Sustainability, Elsevier, 2019, Pages 385-392, https://doi.org/10.1016/B978-0-08-100596-5.22150-1.

Binbin Wang, Qiaozhi Song, Fangkun Zhao, Lixia Zhang, Ye Han, Zhijiang Zhou, Isolation and characterization of dextran produced by Lactobacillus sakei L3 from Hubei sausage, Carbohydrate Polymers, Volume 223, 2019, 115111, https://doi.org/10.1016/j.carbpol.2019.115111.

Shin-Kwon Kim, Won Je Jang, Chae Eun Kim, Su-Jeong Lee, Mi-Hyeon Jeon, Tae-Yong Kim, Hyun-Tai Lee, Jung-Ha Park, Chan-Hee Kim, Jong Min Lee, Eun-Woo Lee, Characterization of Latilactobacillus curvatus MS2 isolated from Korean traditional fermented seafood and cholesterol reduction effect as synbiotics with isomalto-oligosaccharide in BALB/c mice, Biochemical and Biophysical Research Communications, Volume 571, 2021, Pages 125-130, https://doi.org/10.1016/j.bbrc.2021.07.073.

Fangda Sun, Qinxiu Sun, Huan Zhang, Baohua Kong, Xiufang Xia, Purification and biochemical characteristics of the microbial extracellular protease from Lactobacillus curvatus isolated from Harbin dry sausages, International Journal of Biological Macromolecules, Volume 133, 2019, Pages 987-997, https://doi.org/10.1016/j.ijbiomac.2019.04.169.

A. Casaburi, V.D. Martino, P. Ferranti, L. Picariello, F. Villani, Technological properties and bacteriocins production by Lactobacillus curvatus 54M16 and its use as starter culture for fermented sausage manufacture, Food Control 59 (2016) 31-45.

Ferrocino, I., Bellio, A., Giordano, M., Macori, G., Romano, A., Rantsiou, K., Decastelli, L., \& Cocolin, L. (2018). Shotgun Metagenomics and Volatilome Profile of the Microbiota of Fermented Sausages. Applied and Environmental Microbiology, 84(3), e02120-17.

Luca Belleggia, Ilario Ferrocino, Anna Reale, Floriana Boscaino, Tiziana Di Renzo, Maria Rita Corvaglia, Luca Cocolin, Vesna Milanović, Federica Cardinali, Cristiana Garofalo, Francesca Clementi, Lucia Aquilanti, Andrea Osimani, Portuguese cacholeira blood sausage: A first taste of its microbiota and volatile organic compounds, Food Research International, Volume 136, 2020, 109567, https://doi.org/10.1016/j.foodres.2020.109567.

Skåra, T., Axelsson, L., Stefánsson, G., Ekstrand, B., Hagen, H., 2015. Fermented and ripened fish products in the northern European countries. J. Ethn. Foods 2, 18-24.

Jirasak Kongkiattikajorn, Potential of starter culture to reduce biogenic amines accumulation in som-fug, a Thai traditional fermented fish sausage, Journal of Ethnic Foods, Volume 2, Issue 4, 2015, Pages 186-194, https://doi.org/10.1016/j.jef.2015.11.005.

Aquilanti, L., Garofalo, C., Osimani, A., \& Clementi, F. (2016). Ecology of lactic acid bacteria and coagulase negative cocci in fermented dry sausages manufactured in Italy and other Mediterranean countries: An overview. International Food Research Journal, 23, 429-445.

Min Young Jung, Tae-Woon Kim, Changsu Lee, Joon Yong Kim, Hye Seon Song, Yeon Bee Kim, Seung Woo Ahn, Ju Seok Kim, Seong Woon Roh, Se Hee Lee, Role of jeotgal, a Korean traditional fermented fish sauce, in microbial dynamics and metabolite profiles during kimchi fermentation, Food Chemistry, Volume 265, 2018, Pages 135-143, https://doi.org/10.1016/j.foodchem.2018.05.093.

Callahan BJ, McMurdie PJ, Holmes SP. Exact sequence variants should replace operational taxonomic units in marker-gene data analysis. ISME J. 2017 Dec;11(12):2639-2643. doi: 10.1038/ismej.2017.119.

Eugenio Parente, Annamaria Ricciardi, Teresa Zotta, The microbiota of dairy milk: A review, International Dairy Journal,

Volume 107, 2020, 104714, https://doi.org/10.1016/j.idairyj.2020.104714. 
Luca Belleggia, Vesna Milanović, Ilario Ferrocino, Luca Cocolin, M. Naceur Haouet, Stefania Scuota, Antonietta Maoloni, Cristiana Garofalo, Federica Cardinali, Lucia Aquilanti, Massimo Mozzon, Roberta Foligni, Marina Pasquini, Maria Federica Trombetta, Francesca Clementi, Andrea Osimani, Is there any still undisclosed biodiversity in Ciauscolo salami? A new glance into the microbiota of an artisan production as revealed by high-throughput sequencing, Meat Science, Volume 165, 2020, 108128, https://doi.org/10.1016/j.meatsci.2020.108128.

Saithong, P., Panthavee, W., Boonyaratanakornkit, M., \& Sikkhamondhol, C. (2010). Use of a starter culture of lactic acid bacteria in plaa-som, a Thai fermented fish. Journal of Bioscience and Bioengineering, 110, $553 \mathrm{e} 557$.

Sambanduram Samarjit Singh, Surajit De Mandal, Vabeiryureilai Mathipi, Souvik Ghatak, Nachimuthu Senthil Kumar,

Traditional fermented fish harbors bacteria with potent probiotic and anticancer properties, Biocatalysis and Agricultural Biotechnology, Volume 15, 2018, Pages 283-290, https://doi.org/10.1016/j.bcab.2018.07.007.

Ju Meng, Qin Yang, Weiyang Wan, Qiujin Zhu, Xuefeng Zeng, Physicochemical properties and adaptability of amine-producing Enterobacteriaceae isolated from traditional Chinese fermented fish (Suan yu), Food Chemistry, Volume 369,

2022, 130885, https://doi.org/10.1016/j.foodchem.2021.130885.

Ameer Khusro, Chirom Aarti, Azger Dusthackeer, Paul Agastian, Anti-tubercular and probiotic properties of coagulase-negative staphylococci isolated from Koozh, a traditional fermented food of South India, Microbial Pathogenesis, Volume 114, 2018, Pages 239-250, https://doi.org/10.1016/j.micpath.2017.11.054.

Debajit Borah, Olee Gogoi, Chanakya Adhikari, B.B. Kakoti, Isolation and characterization of the new indigenous Staphylococcus sp. DBOCP06 as a probiotic bacterium from traditionally fermented fish and meat products of Assam state, Egyptian Journal of Basic and Applied Sciences, Volume 3, Issue 3, 2016, Pages 232-240, https://doi.org/10.1016/j.ejbas.2016.06.001.

Yueqi Zhou, Shumeng Wu, Yulu Peng, Yamei Jin, Dan Xu, Xueming Xu, Effect of lactic acid bacteria on mackerel (Pneumatophorus japonicus) seasoning quality and flavor during fermentation, Food Bioscience, Volume 41, 2021, 100971, https://doi.org/10.1016/j.fbio.2021.100971.

Natteewan Udomsil, Sureelak Rodtong, Somboon Tanasupawat, Jirawat Yongsawatdigul, Proteinaseproducing halophilic lactic acid bacteria isolated from fish sauce fermentation and their ability to produce volatile compounds, International Journal of Food Microbiology, Volume 141, Issue 3, 2010, Pages 186-194, https://doi.org/10.1016/j.ijfoodmicro.2010.05.016.

Luca Belleggia, Vesna Milanović, Cristiana Cesaro, Federica Cardinali, Cristiana Garofalo, Lucia Aquilanti \& Andrea Osimani (2021) Exploratory Study on Histamine Content and Histidine Decarboxylase Genes of Gram-positive Bacteria in Hákarl, Journal of Aquatic Food Product Technology, 30:7, 907-913, DOI: $10.1080 / 10498850.2021 .1948478$

Yongjin $\mathrm{Hu}$, Wenshui Xia, Changrong Ge, Characterization of fermented silver carp sausages inoculated with mixed starter culture, LWT - Food Science and Technology, Volume 41, Issue 4, 2008, Pages 730-738, https://doi.org/10.1016/j.lwt.2007.04.004.

Zhang, Q., Lin, S., \& Nie, X. (2013). Reduction of biogenic amine accumulation in silver carp sausage by an amine-negative Lactobacillus plantarum. Food Control, 32(2), 496-500. https://doi.org/10.1016/j.foodcont.2013.01.029.

Yue Zhao, Yueqi Wang, Chunsheng Li, Laihao Li, Xianqing Yang, Yanyan Wu, Shengjun Chen, Yongqiang Zhao, Novel insight into physicochemical and flavor formation in naturally fermented tilapia sausage based on microbial metabolic network, Food Research International, Volume 141, 2021, 110122, https://doi.org/10.1016/j.foodres.2021.110122. 
Chunsheng Li, Yue Zhao, Yueqi Wang, Laihao Li, Xianqing Yang, Shengjun Chen, Yongqiang Zhao, Wenguo Zhou, Microbial community changes induced by Pediococcus pentosaceus improve the physicochemical properties and safety in fermented tilapia sausage, Food Research International, Volume 147, 2021, 110476, https://doi.org/10.1016/j.foodres.2021.110476.

Lucas PM, Wolken WA, Claisse O, Lolkema JS, Lonvaud-Funel A (2005) Histamine-producing pathway encoded on an unstable plasmid in Lactobacillus hilgardii 0006. Appl Environ Microbiol 71:1417-1424. https://doi.org/10.1128/AEM.71.3.1417-1424.2005

Diaz M, Ladero V, Redruello B, Sanchez-Llana E, del Rio B, Fernandez M, Cruz Martin M, Alvarez MA (2016) Nucleotide sequence alignment of hdcA from Gram-positive bacteria. Data Brief 6:674-679. https://doi.org/10.1016/j.dib.2016.01.020

Khem, S., Young, O.A., Robertson, J.D., Brooks, J.D. 2013. Development of Model Fermented Fish Sausage from Marine Species: A Pilot Physicochemical Study.Food and Nutrition Sciences, 4, 1229-1238. http://dx.doi.org/10.4236/fns.2013.412157

Fong, F.L.Y., El-Nezami, H., Sze, E.T.P., 2021. Biogenic amines - Precursors of carcinogens in traditional Chinese fermented food. NFS Journal, 23, 52-57. https://doi.org/10.1016/j.nfs.2021.04.002

Zotta, T., Ricciardi, A., Ianniello, R.G., Storti, L.V., Glibota, N.A., Parente, E., 2018. Aerobic and respirative growth of heterofermentative lactic acid bacteria: A screening study. Food Microbiology, 76, 117-127. https://doi.org/10.1016/j.fm.2018.02.017

Zhou, Y., Wu, S., Peng, Y., Jin, Y., Xu, D., Xu, X. 2021. Effect of lactic acid bacteria on mackerel (Pneumatophorus japonicus) seasoning quality and flavor during fermentation. Food Bioscience, 41, 100971. https://doi.org/10.1016/j.fbio.2021.100971

Mouritsen, O.G., Lars Duelund, Ghislaine Calleja, Michael Bom Frøst, 2017. Flavour of fermented fish, insect, game, and pea sauces: Garum revisited, International Journal of Gastronomy and Food Science, 9, 16-28, https://doi.org/10.1016/j.ijgfs.2017.05.002

Marti-Quijal, F.J., Fabienne Remize, Giuseppe Meca, Emilia Ferrer, María-José Ruiz, Francisco J Barba, 2020. Fermentation in fish and by-products processing: an overview of current research and future prospects, Current Opinion in Food Science, 31, 9-16. https://doi.org/10.1016/j.cofs.2019.08.001

Jang, G.I., Gahee Kim, Chung Yeon Hwang, Byung Cheol Cho, 2017. Prokaryotic community composition in $\begin{array}{llllll}\text { alkaline-fermented } \quad \text { skate } \quad \text { (Raja pulchra), } & \text { Food } & \text { Microbiology, } & 61,82 .\end{array}$ https://doi.org/10.1016/j.fm.2016.08.008

Zhao, C.-C., Du-Woon Kim, Jong-Bang Eun, 2019. Physicochemical properties and bacterial community dynamics of hongeo, a Korean traditional fermented skate product, during fermentation at $10^{\circ} \mathrm{C}, \mathrm{LWT}, 104$, 109-119. https://doi.org/10.1016/j.lwt.2019.01.048

Andrea Osimani, Cristiana Garofalo, Lucia Aquilanti, Vesna Milanović, Francesca Clementi, Unpasteurised commercial boza as a source of microbial diversity, International Journal of Food Microbiology, Volume 194, 2015, Pages 62-70, https://doi.org/10.1016/j.ijfoodmicro.2014.11.011.

Anna Klindworth, Elmar Pruesse, Timmy Schweer, Jörg Peplies, Christian Quast, Matthias Horn, Frank Oliver Glöckner, Evaluation of general 16S ribosomal RNA gene PCR primers for classical and next-generation sequencing-based diversity studies, Nucleic Acids Research, Volume 41, Issue 1, 1 January 2013, Page e1, https://doi.org/10.1093/nar/gks808

Mota-Gutierrez, J., Botta, C., Ferrocino, I., Giordano, M., Bertolino, M., Dolci, P., \& Cocolin, L. (2018). Dynamics and biodiversity of bacterial and yeast communities during fermentation of cocoa beans. Applied and Environmental Microbiology, 84(19), e01164-18. 
Bolyen E, Rideout JR, Dillon MR, Bokulich NA, Abnet CC, Al-Ghalith GA, Alexander H, Alm EJ, Arumugam M, Asnicar F, Bai Y, Bisanz JE, Bittinger K, Brejnrod A, Brislawn CJ, Brown CT, Callahan BJ, CaraballoRodríguez AM, Chase J, Cope EK, Da Silva R, Diener C, Dorrestein PC, Douglas GM, Durall DM, Duvallet C, Edwardson CF, Ernst M, Estaki M, Fouquier J, Gauglitz JM, Gibbons SM, Gibson DL, Gonzalez A, Gorlick K, Guo J, Hillmann B, Holmes S, Holste H, Huttenhower C, Huttley GA, Janssen S, Jarmusch AK, Jiang L, Kaehler BD, Kang KB, Keefe CR, Keim P, Kelley ST, Knights D, Koester I, Kosciolek T, Kreps J, Langille MGI, Lee J, Ley R, Liu YX, Loftfield E, Lozupone C, Maher M, Marotz C, Martin BD, McDonald D, McIver LJ, Melnik AV, Metcalf JL, Morgan SC, Morton JT, Naimey AT, Navas-Molina JA, Nothias LF, Orchanian SB, Pearson T, Peoples SL, Petras D, Preuss ML, Pruesse E, Rasmussen LB, Rivers A, Robeson MS 2nd, Rosenthal P, Segata N, Shaffer M, Shiffer A, Sinha R, Song SJ, Spear JR, Swafford AD, Thompson LR, Torres PJ, Trinh P, Tripathi A, Turnbaugh PJ, Ul-Hasan S, van der Hooft JJJ, Vargas F, Vázquez-Baeza Y, Vogtmann E, von Hippel M, Walters W, Wan Y, Wang M, Warren J, Weber KC, Williamson CHD, Willis AD, Xu ZZ, Zaneveld JR, Zhang Y, Zhu Q, Knight R, Caporaso JG. Reproducible, interactive, scalable and extensible microbiome data science using QIIME 2. Nat Biotechnol. 2019 Aug;37(8):852-857. doi: 10.1038/s41587-0190209-9. Erratum in: Nat Biotechnol. 2019 Sep;37(9):1091. PMID: 31341288; PMCID: PMC7015180.

Callahan BJ, McMurdie PJ, Rosen MJ, Han AW, Johnson AJ, Holmes SP. DADA2: High-resolution sample inference from Illumina amplicon data. Nat Methods. 2016 Jul;13(7):581-3. doi: 10.1038/nmeth.3869. Epub 2016 May 23. PMID: 27214047; PMCID: PMC4927377.

https://doi.org/10.1101/074252 (EDGAR 2016)

Vauterin L, Vauterin P. 1992. Computer-aided objective comparison of electrophoresis patterns for grouping and identification of microorgan- isms. Eur J Clin Microbiol 1:37-41.

Belleggia L, Milanović V, Cardinali F, Garofalo C, Clementi F, Aquilanti L, Osimani A. Prevalence of Histidine Decarboxylase Genes of Gram-Positive Bacteria in Surströmming as Revealed by qPCR. Indian J Microbiol. 2021 Mar;61(1):96-99. doi: 10.1007/s12088-020-00907-1. Epub 2020 Sep 22. PMID: 33505099; PMCID: PMC7810795.

Fernández M, del Rio B, Linares DM, Mart1'n M, Alvarez M (2006) Real-time polymerase chain reaction for quantitative detection of histamine-producing bacteria: use in cheese production.

J Dairy Sci 89:3763-3769. https://doi.org/10.3168/jds.

S0022-0302(06)72417-1

Satomi M (2016) Effect of histamine-producing bacteria on fermented fishery products. Food Sci Technol Res 22:1-21. https://

doi.org/10.3136/fstr.22.1

Eugenio Parente; Carla Brienza; Marcella Moles; Annamaria Ricciardi (1995). A comparison of methods for the measurement of bacteriocin activity. , 22(1), 0-108. doi:10.1016/0167-7012(94)00068-i

Andrea Osimani, Cristiana Garofalo, Lucia Aquilanti, Vesna Milanović, Francesca Clementi, Unpasteurised commercial boza as a source of microbial diversity, International Journal of Food Microbiology, Volume 194, 2015, Pages 62-70, https://doi.org/10.1016/j.ijfoodmicro.2014.11.011.

Anna Klindworth, Elmar Pruesse, Timmy Schweer, Jörg Peplies, Christian Quast, Matthias Horn, Frank Oliver Glöckner, Evaluation of general 16S ribosomal RNA gene PCR primers for classical and next-generation sequencing-based diversity studies, Nucleic Acids Research, Volume 41, Issue 1, 1 January 2013, Page e1, https://doi.org/10.1093/nar/gks808 
Mota-Gutierrez, J., Botta, C., Ferrocino, I., Giordano, M., Bertolino, M., Dolci, P., \&

Cocolin, L. (2018). Dynamics and biodiversity of bacterial and yeast communities

during fermentation of cocoa beans. Applied and Environmental Microbiology, 84(19),

e01164-18.

Bolyen E, Rideout JR, Dillon MR, Bokulich NA, Abnet CC, Al-Ghalith GA, Alexander H, Alm EJ, Arumugam M, Asnicar F, Bai Y, Bisanz JE, Bittinger K, Brejnrod A, Brislawn CJ, Brown CT, Callahan BJ, CaraballoRodríguez AM, Chase J, Cope EK, Da Silva R, Diener C, Dorrestein PC, Douglas GM, Durall DM, Duvallet C, Edwardson CF, Ernst M, Estaki M, Fouquier J, Gauglitz JM, Gibbons SM, Gibson DL, Gonzalez A, Gorlick K, Guo J, Hillmann B, Holmes S, Holste H, Huttenhower C, Huttley GA, Janssen S, Jarmusch AK, Jiang L, Kaehler BD, Kang KB, Keefe CR, Keim P, Kelley ST, Knights D, Koester I, Kosciolek T, Kreps J, Langille MGI, Lee J, Ley R, Liu YX, Loftfield E, Lozupone C, Maher M, Marotz C, Martin BD, McDonald D, McIver LJ, Melnik AV, Metcalf JL, Morgan SC, Morton JT, Naimey AT, Navas-Molina JA, Nothias LF, Orchanian SB, Pearson T, Peoples SL, Petras D, Preuss ML, Pruesse E, Rasmussen LB, Rivers A, Robeson MS 2nd, Rosenthal P, Segata N, Shaffer M, Shiffer A, Sinha R, Song SJ, Spear JR, Swafford AD, Thompson LR, Torres PJ, Trinh P, Tripathi A, Turnbaugh PJ, Ul-Hasan S, van der Hooft JJJ, Vargas F, Vázquez-Baeza Y, Vogtmann E, von Hippel M, Walters W, Wan Y, Wang M, Warren J, Weber KC, Williamson CHD, Willis AD, Xu ZZ, Zaneveld JR, Zhang Y, Zhu Q, Knight R, Caporaso JG. Reproducible, interactive, scalable and extensible microbiome data science using QIIME 2. Nat Biotechnol. 2019 Aug;37(8):852-857. doi: 10.1038/s41587-0190209-9. Erratum in: Nat Biotechnol. 2019 Sep;37(9):1091. PMID: 31341288; PMCID: PMC7015180.

Callahan BJ, McMurdie PJ, Rosen MJ, Han AW, Johnson AJ, Holmes SP. DADA2: High-resolution sample inference from Illumina amplicon data. Nat Methods. 2016 Jul;13(7):581-3. doi: 10.1038/nmeth.3869. Epub 2016 May 23. PMID: 27214047; PMCID: PMC4927377.

https://doi.org/10.1101/074252 (EDGAR 2016)

Vauterin L, Vauterin P. 1992. Computer-aided objective comparison of electrophoresis patterns for grouping and identification of microorgan- isms. Eur J Clin Microbiol 1:37-41.

Belleggia L, Milanović V, Cardinali F, Garofalo C, Clementi F, Aquilanti L, Osimani A. Prevalence of Histidine Decarboxylase Genes of Gram-Positive Bacteria in Surströmming as Revealed by qPCR. Indian J Microbiol. 2021 Mar;61(1):96-99. doi: 10.1007/s12088-020-00907-1. Epub 2020 Sep 22. PMID: 33505099; PMCID: PMC7810795.

Fernández M, del Rio B, Linares DM, Martı'n M, Alvarez M (2006) Real-time polymerase chain reaction for quantitative detection of histamine-producing bacteria: use in cheese production. J Dairy Sci 89:3763-3769. https://doi.org/10.3168/jds.

S0022-0302(06)72417-1

Satomi M (2016) Effect of histamine-producing bacteria on fermented fishery products. Food Sci Technol Res 22:1-21. https://

doi.org/10.3136/fstr.22.1

Eugenio Parente; Carla Brienza; Marcella Moles; Annamaria Ricciardi (1995). A comparison of methods for the measurement of bacteriocin activity. , 22(1), 0-108. doi:10.1016/0167-7012(94)00068-i

Jonas Hilbig, Julia Gisder, Roman M. Prechtl, Kurt Herrmann, Jochen Weiss, Myriam Loeffler, Influence of exopolysaccharide-producing lactic acid bacteria on the spreadability of fat-reduced raw fermented sausages 
(Teewurst), Food Hydrocolloids, Volume 93, 2019, Pages 422-431, https://doi.org/10.1016/j.foodhyd.2019.01.056.

Stolz, P., Bocker, G., Hammes, W. P., \& Vogel, R. F. (1995). Utilization of electron-acceptors by lactobacilli isolated from sourdough. Zeitschrift Fur Lebensmittel-

Untersuchung Und-Forschung, 201(1), 91-96. https://doi.org/10.1007/Bf01193208

Milanović, V., Osimani, A., Garofalo, C., Belleggia, L., Maoloni, A., Cardinali, F., Mozzon, M., Foligni, R., Aquilanti, L., \& Clementi, F. (2020). Selection of cereal-sourced lactic acid bacteria as candidate starters for the baking industry. PloS one, 15(7), e0236190. https://doi.org/10.1371/journal.pone.0236190

Palomba S, Cavella S, Torrieri E, Piccolo A, Mazzei P, Blaiotta G, et al. Polyphasic screening, homopolysaccharide

composition, and viscoelastic behavior of wheat sourdough from a Leuconostoc lactis and

Lactobacillus curvatus exopolysaccharide-producing starter culture. Appl Environ Microbiol. 2012; 78

(8): 2737-2747. https://doi.org/10.1128/AEM.07302-11

Claudio Eduardo dos Santos Cruxen, Graciele Daiana Funck, Louise Haubert, Guilherme da Silva Dannenberg, Juliana de Lima Marques, Fabio Clasen Chaves, Wladimir Padilha da Silva, Ângela Maria Fiorentini, Selection of native bacterial starter culture in the production of fermented meat sausages: Application potential, safety aspects, and emerging technologies,

Food Research International, Volume 122,

2019, Pages 371-382, https://doi.org/10.1016/j.foodres.2019.04.018. 


\section{FIGURE CAPTIONS}

Fig. 1. Relative frequency of the bacterial ASVs detected by sequencing. Only ASVs with an incidence above $0.5 \%$ in at least two samples are shown.
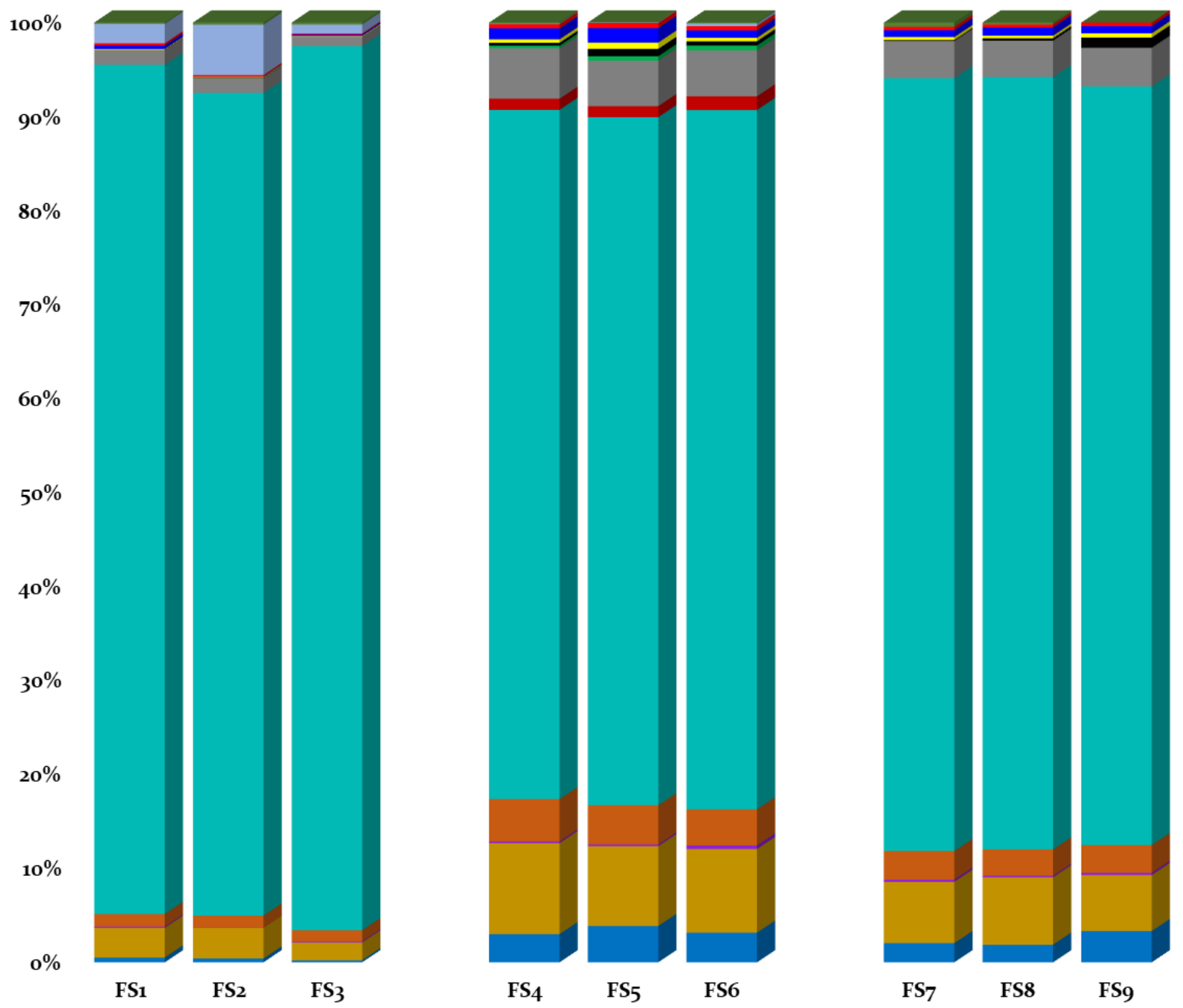

- Turicibacter

- Staphylococcus succinus

- Rummeliibacillus

- Ruminococcus

Psychrobacter

- Prevotella

- Photobacterium

- Peptostreptococcus

- Leuconostoc

- Latilactobacillus sakei

- Latilactobacillus curvatus

- Lachnospira

- Clostridium

- Bacteroides 
Fig. 2. Relative frequency of the fungal ASVs detected by sequencing. Only ASVs with an incidence above $0.5 \%$ in at least two samples are shown.

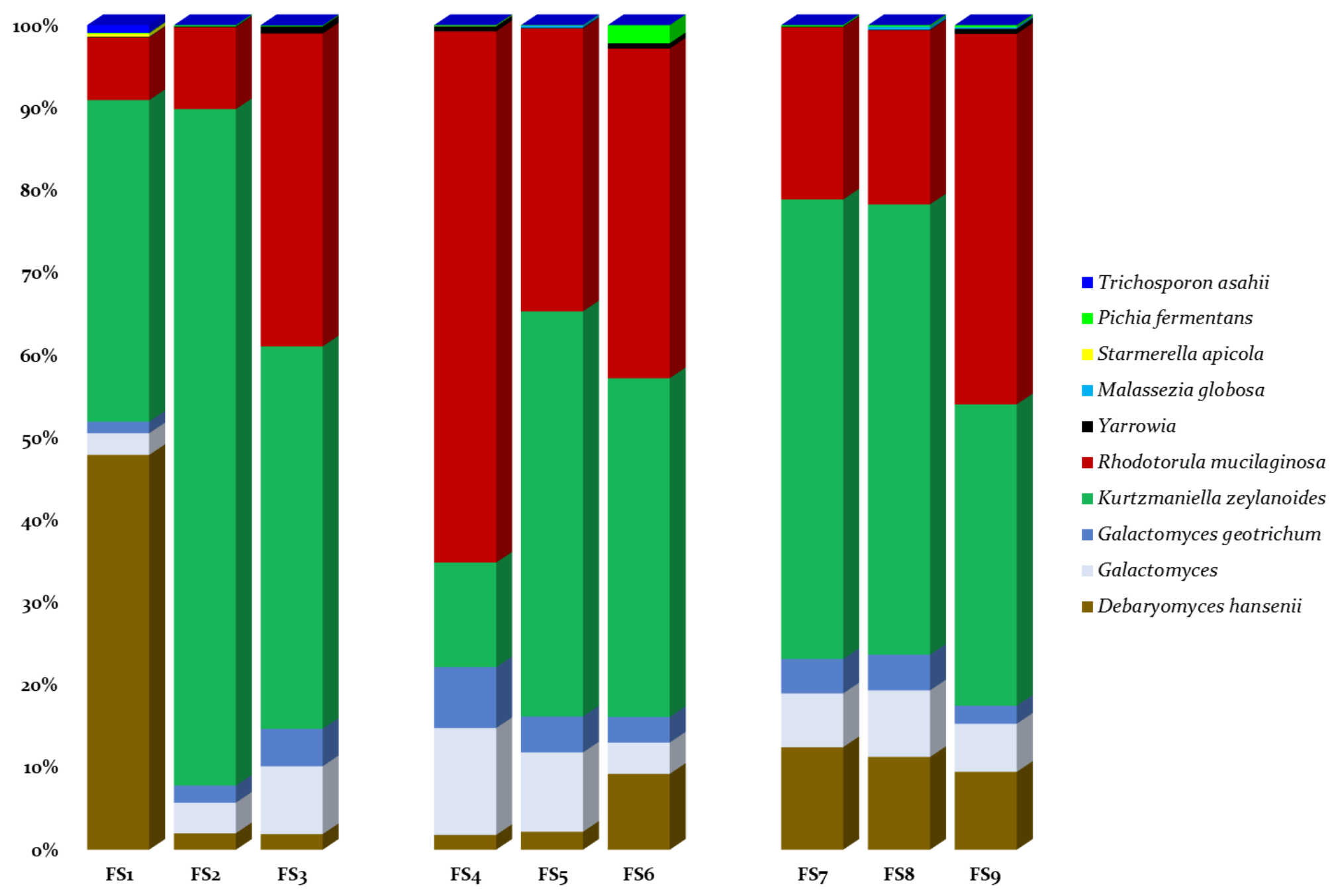


Fig. 3. Principal coordinates analysis based (PCoA) based on L. sakei and L. curvatus Rep fingerprints. The samples are color-coded according to the batch (A, blue; B, red; and C, green).

a)

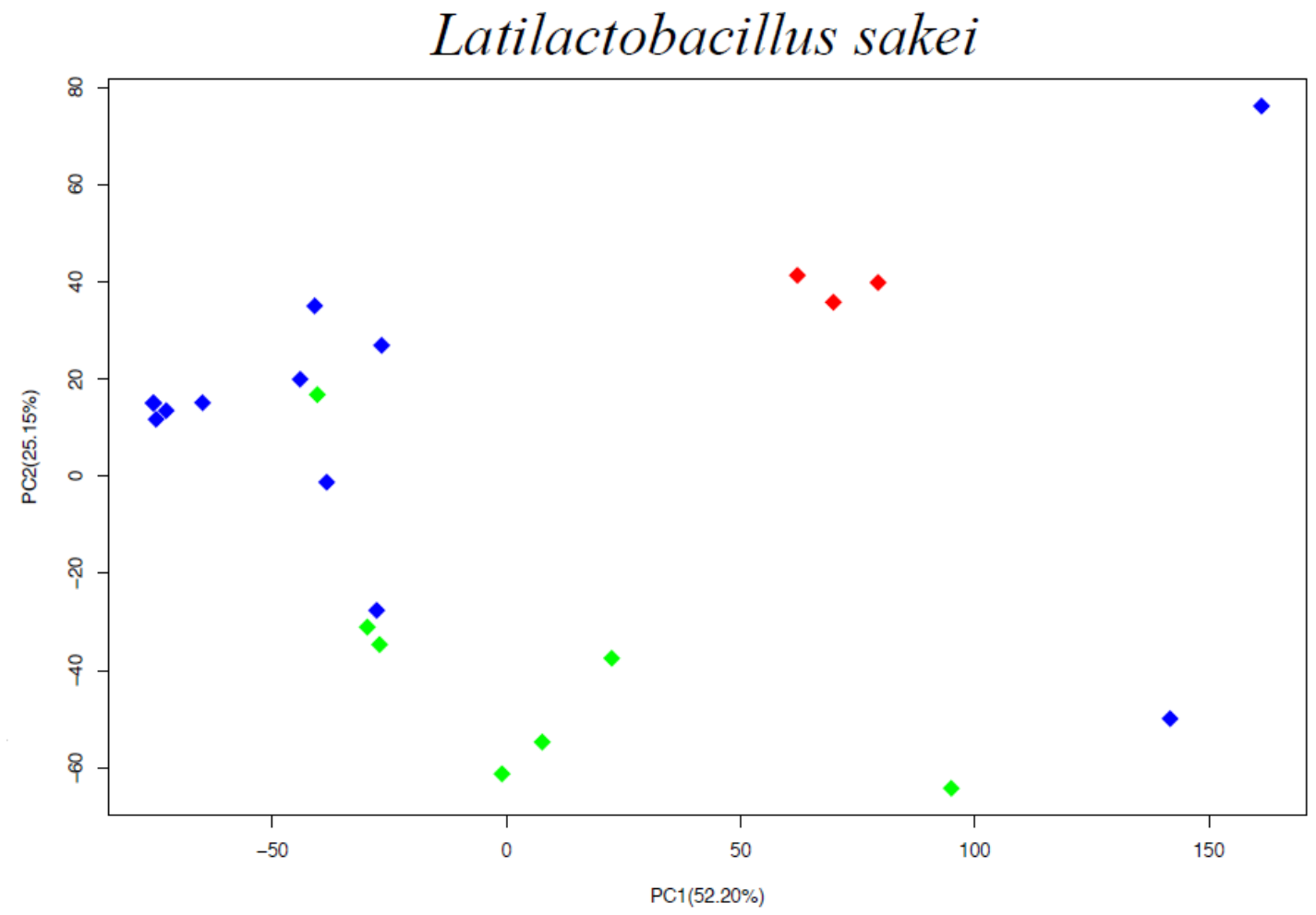

b)

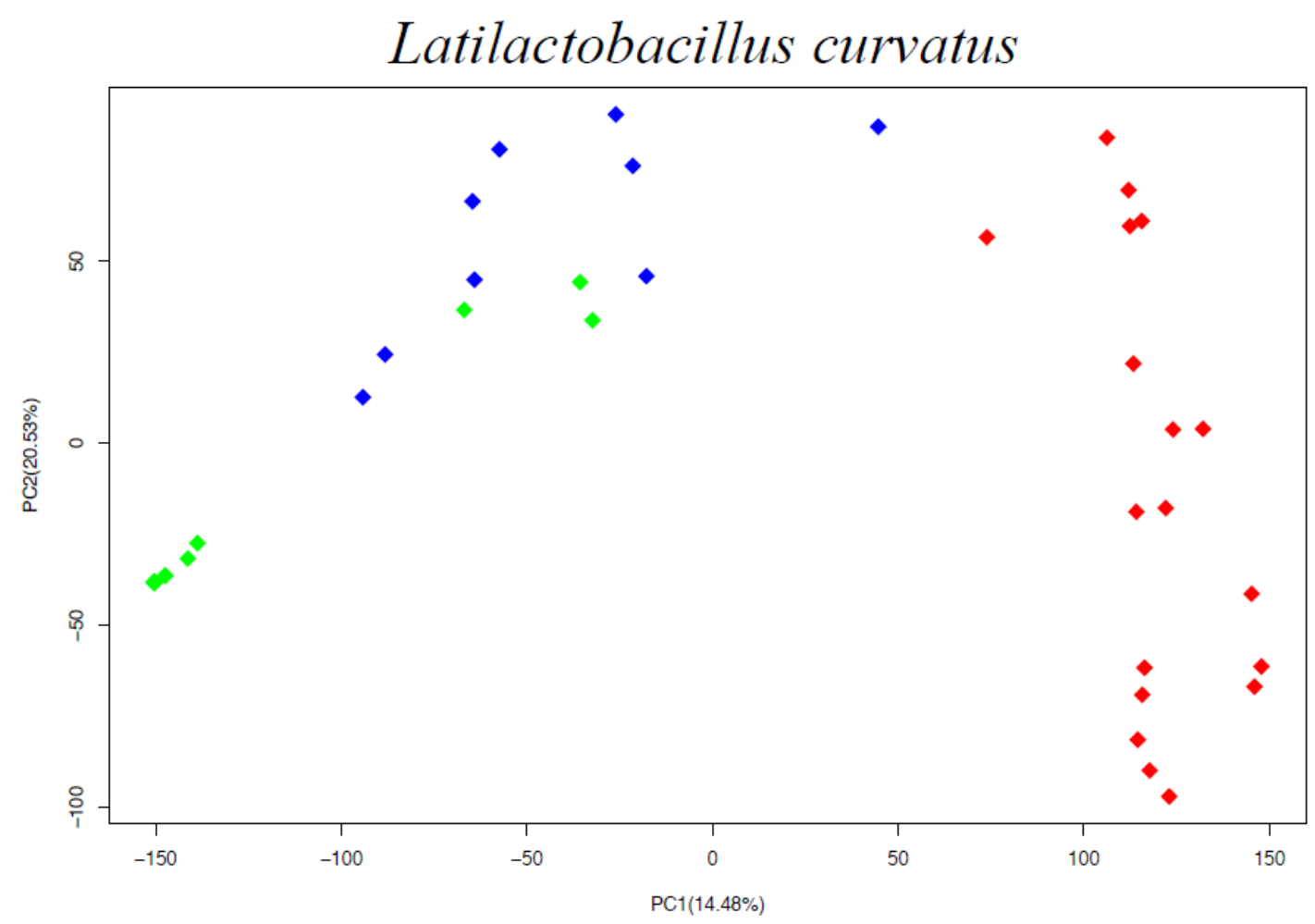

